\title{
The Aksumites in South Arabia: An African Diaspora of Late Antiquity
}

\author{
George Hatke
}

Much has been written over the years about foreign, specifically western, colonialism in sub-Saharan Africa, as well as about the foreign peoples, western and non-western alike, who have settled in sub-Saharan Africa during the modern period. However, although many large-scale states rose and fell in subSaharan Africa throughout pre-colonial times, the history of African imperial expansion into non-African lands is to a large degree the history of Egyptian invasions of Syria-Palestine during Pharaonic and Ptolemaic times, Carthaginian (effectively Phoenician) expansion into Sicily and Spain in the second half of the first millennium B.C.E, and the Almoravid and Almohad invasions of the Iberian Peninsula during the Middle Ages. However, none of this history involved sub-Saharan Africans to any appreciable degree. Yet during Late Antiquity, ${ }^{1}$ Aksum, a sub-Saharan African kingdom based in the northern Ethiopian highlands, invaded its neighbors across the Red Sea on several occasions. Aksum, named after its capital city, was during this time an active participant in the long-distance sea trade linking the Mediterranean with India via the Red Sea. It was a literate kingdom with a tradition of monumental art and architecture and already a long history of contact with South Arabia. The history of Aksumite expansion into, and settlement in, South Arabia can be divided into two main periods. The first lasts from the late 2 nd to the late 3 rd century

1 Although there is disagreement among scholars as to the chronological limits of "Late Antiquity" - itself a modern concept - the term is, for the purposes of the present study, used to refer to the period from ca. 200 A.D. until the fall of the Umayyad Dynasty in $75^{\circ}$. It should be noted that the period within which the Ethiopian kingdom of Aksum held sway only partially overlaps with the timeframe for Late Antiquity adopted here, while the period within which Aksum was active in South Arabia began sometime before 200 and ended nearly two centuries before 750 . 
A.D. ${ }^{2}$ and witnessed Aksum's entry into direct contact, for better or worse, with the South Arabian kingdoms of Saba' and Himyar. The second began around the turn of the 6th century and is characterized by the appointment of local vassal kings, brought to power through military invasions, to rule Himyar on Aksum's behalf. Although the period of direct Aksumite rule of Himyar ended sometime between 531 and 540, Ethiopians of Aksumite origin maintained an importance presence in South Arabia. Only with the conquest of South Arabia by the Sāsānid Persians ca. 570 was Ethiopian rule brought to an end.

In addition to their military and political activities in South Arabia, the Aksumites were also active in the region as merchants. Of such commercial activities South Arabian inscriptions have nothing to say, though it must be stressed that direct references to commerce are relatively rare in such inscriptions during all periods. As we shall see, ${ }^{3}$ ceramic evidence from Qāni', located on the southern coast of Yemen, indicates an Aksumite presence there. Apart from Qāni', however, archaeology has until now brought to light little data pertaining to the Aksumite presence in South Arabia at large. Even Zafār, the capital of Himyar and a town at which the Aksumites are known to have established a significant presence, has yielded no more than a single potsherd of (possible) Aksumite origin. ${ }^{4}$

Before proceeding, a few words about the terms used for the Aksumites and their settlements in South Arabia are in order. Inscriptions in the Sabaic language, left by both Sabaeans and Himyarites, refer to the African subjects of Aksum as either "Aksumites" ' $k s^{1} m^{n}\left({ }^{*} A k s \bar{u} m^{a n}\right)$ or as "Ethiopians" ' $h b s^{2 n}$

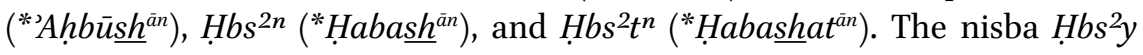
$\left({ }^{*} \mathrm{Habash} \bar{\imath}\right)$ "Ethiopian" is also attested. ${ }^{5}$ It is likely that the former ethnonym designates specifically the Ge'ez-speaking inhabitants of the city of Aksum and its environs, while the latter refers to the various other groups dwelling in the northern highlands of Ethiopia who were subject to Aksum. In addition, armed divisions of Aksumites are designated in Sabaic by the term 'hzb ( ${ }^{*} a h z \bar{a} b$ ), which is derived from Ge'ez hazb "people, tribe, crowd, nation" but is attested in Sabaic only in the plural form (cf. Ge'ez pl. 'ahzāa). The singular form is, however, used in a 6th century Syriac text, the Letter of Pseudo-Simeon of Bēth Arsham, which in one instance seems to refer to the Aksumite residents in South Arabia as hezb $\bar{a} .{ }^{6}$ A number of Sabaic inscriptions allude to the

2 Except where otherwise noted, all dates mentioned henceforth refer to years of the Common Era (A.D.).

3 See $\S 4$.

4 Yule, Late Antique Arabia, pp. 104; 105.

5 Ja 576+Ja 577/28 (Jamme, Sabaean Inscriptions, pp. 77; 78-79 [line 12]).

6 Shahid, Martyrs, p. iii (Syriac text). 
settlements established by the Aksumites in South Arabia, specifically in the

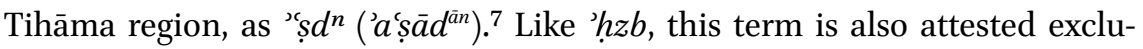
sively in the plural form in Sabaic and is derived from Ge'ez ('așad "village, farm, enclosed area, field"; pl. 'așa $\bar{c}$ ). To date, these Aksumite settlements are known only from Sabaic inscriptions and might well have been of an ephemeral nature-perhaps camps, or at most small villages, rather than towns. If and when it becomes possible once more to conduct research in Yemen, archaeological surveys of the Tihāma may well locate such settlements. In Syriac sources, Aksumites are generally referred to as Küšāye (sg. Kūšăyā), literally "Kushites", Egyptian $K_{3} \check{s}$ ), but at times as Hendwāye (sg. Hendwāya ), literally "Indian", the latter a very fluid term that occasionally designates South Arabians, in addition to people from India proper. Greek sources, though at times referring to the Aksumites as 'A $\xi \omega \mu \tau \hat{\omega} \nu$, more commonly calls them simply Ai ans". The latter ethnonym, like Syriac Küšāyēe, referred originally to the Nubians but was adopted by the Aksumites in the mid-4th century as the equivalent of Ge'ez Habaśat (> Sabaic $\left.\mathrm{Hbs}^{2} t\right)^{9}$ and is used for the first time by the ecclesiastical historian Philostorgius (d. 433) as a generic term for the Aksumites. ${ }^{10}$ Finally, medieval Arabic authors designate the Aksumites by the generic term for Ethiopians, al-Habasha, less commonly al-Südān "the blacks". A few such authors knew of a town or region called Aksüm or Akhshüm-the latter form reflecting the Tigrinya pronunciation ${ }^{11}$ —and were even vaguely aware of its ancient past ${ }^{12}$ but, while Aksüm is attested as a personal name in Arabic sources, ${ }^{13}$ the Aksumites are never referred to as such in Arabic.

$7 \quad$ For an extended discussion of such settlements, see Shitomi, "Note".

8 Only once in Syriac literature, in the Ecclesiastical History of John of Ephesus (d. 586/8), are the Aksumites referred to as 'Aksimițōn, a calque on Greek 'A $\xi \omega \mu \iota \tau \omega$ v (Hatke, Aksum and Nubia, p. 161 [n. 681]). Since the relevant passage deals with a group of Aksumite visitors to the Nubian kingdom of Alodia, it has no bearing on the present discussion.

9 Hatke, Aksum and Nubia, p. 52.

10 Murray, "Review: East of Suez", p. 80.

11 Hayajneh, "Abessinisches", p. 505.

12 The Egyptian historian Ahmad bin 'Alī al-Maqrīzì (d. 1442) and the 16th-century Yemeni scholar Shihāb al-Dīn bin 'Abd al-Qādir 'Arabfaqīh are both aware that Aksum was an ancient city (Hayajneh, "Abessinisches", pp. 502-503; 'Arabfaqīh, Tuhfat al-zamān, ed. Shaltūt, p. 322), while Muḥammad bin 'Abd Allāh al-Azraqī (d. ca. 865) mentions "the land of Aksum" (bilād Aksūm) as the place where the Ethiopian king resided (al-Azraqī, $A \underline{k h} b \bar{a} r$ makka, ed. al-Ṣālị̣ Malḥas, p. 137).

13 E.g. al-Aksūm bin Aswad bin Yāsir in the genealogy of the South Arabian tribe of Dhū-Manākh preserved by al-Ḥasan bin Aḥmad al-Hamdānī (d. 950s) in his Kitāb al-Iklīl (Müller, “Aksum", p. 220). 
The African and Arabian sides of the Red Sea have been in contact since prehistory. One of the most significant long-term results of this contact was the diffusion of Semitic speech from South Arabia to the Horn of Africa. Attempting to determine a precise date for this development is all but impossible and, since the diffusion of Semitic speech was undoubtedly a long process, inappropriate. Whatever the case, a turning point in relations between the two sides of the Red Sea came in the first half of the first millennium B.c. when South Arabia, in particular the kingdom of Saba', began exerting a significant cultural impact on northern Ethiopia, one aspect of which was the use of the Sabaic language and the South Arabian musnad script in inscriptions. That a pre-Sabaean Semitic language or group of languages already existed in Ethiopia at this time is evident from the lexical and morphological idiosyncrasies which occur in Sabaic inscriptions from Ethiopia but are absent in the ancient inscriptions from South Arabia. ${ }^{14}$ Likewise, the Ethiopian branch of Semitic, which includes such languages as Ge'ez, Amharic, Tigrinya, and Tigre, is characterized by numerous morphological features not attested in any of the written languages of ancient South Arabia, which strongly suggests that an older form of Semitic was introduced to the Horn of Africa well before the first millennium B.c.

The Sabaic inscriptions that have come to light in northern Ethiopia preserve the names of several kings who reigned during the first half of the 1st millennium в.c. What their polity was called is unknown, and while scholars have long assumed that this early Ethiopian kingdom was called Di'mat, this name, while attested in some Sabaic inscriptions from Ethiopia, does not occur in all of the attested royal titles. The same corpus of inscriptions indicates that several South Arabian deities were worshipped in Ethiopia during this period, namely 'Īlmuquh, 'Athtar, Hawbas, and Dhāt-Ḥimāyim, together with such local deities as Yãf ${ }^{\text {cum }}$, Naraw, 'Aybas, Shayḥ̣ ${ }^{\text {an }}$, and Șādiqa ${ }^{a n}$. From these inscriptions, we also learn of the presence in Ethiopia of a community of South Arabian expatriates hailing from the Sabaean capital of Mārib and from the town of Hadaq ${ }^{\text {an }}$, the capital of the small kingdom of Sam'i based in the Yemeni highlands. A number of these resident South Arabians bear the title of grby, which translates as "stonemason" but which also designates a cadre of specialist who at times, at least in South Arabia, occupied ministerial positions at the royal court..$^{15}$ In Ethiopia, such individuals were effectively agents of

\footnotetext{
14 Robin in Robin/de Maigret, "Grand Temple”, pp. 784-787; Kropp, "Sabäisch", p. 333.

15 Maraqten, "Inschrift aus Mārib”, p. 244.
} 
South Arabian cultural influence. Although one might assume the presence of a parallel community of Ethiopians in South Arabia, no trace of such a community survives in the archaeological or epigraphic record in the first half of the first millennium в.c.

In the second half of the 1st millennium B.C., northern Ethiopia entered an obscure period during which the South Arabian cultural influence gradually diminished. Although it is impossible to discern any semblance of a coherent history during this period, it is likely that the region became divided between several small-scale polities. The picture becomes clearer when Aksum emerged as the dominant polity sometime around the turn of the Common Era, a development that led to a revival-indeed an expansion-of Ethiopian contact with the outside world. The Periplus of the Erythraean Sea, a Greek text dating from the mid-1st century which served as a guide for merchants conducting business in the Red Sea and the western Indian Ocean, describes the Aksumite town of Adulis, located near the Red Sea coast in what is now Eritrea, as a bustling center of trade at which ivory, tortoise shell, and rhinoceros horn were exchanged for cloth, garments, tools, weapons, and iron from places as far afield as the Roman Empire and northwestern India. ${ }^{16}$ According to the Periplus, the Aksumite king of the time was literate in Greek, ${ }^{17}$ and indeed Greek continued to be used in royal inscriptions, side by side with Ge'ez, down to the 4th century. Thus, far from being barbarian marauders, the Aksumites who intervened militarily — and at times settled — in South Arabia hailed from an affluent, cosmopolitan kingdom that engaged in long-distance trade. Material evidence of this affluence survives in the form of large-scale elite residences and tombs at Aksum, ${ }^{18}$ as well as archaeological and numismatic evidence for trade with the Roman Empire and India. ${ }^{19}$

Although Aksumite merchants were undoubtedly present in South Arabia from at least the ist century, it is not until the second half of the 2nd century that the Aksumites make an appearance in South Arabian inscriptions. They entered the South Arabian political arena during a period of intense warfare between the kingdoms of Saba', Ḥimyar, Qatabān, and Ḥaḍramawt. Of these,

\footnotetext{
16 Casson, Periplus, $\$ 6.2 .23-\$ 6.3 .4$.

17 Casson, Periplus, \$5.2.16-22.

18 Phillipson, Foundations, pp. 90; 124-125; 139-157.

19 Phillipson, Foundations, pp. 49-50; 197-200.
} 
Qatabān was the first to collapse, its territories in the southwest having been gradually annexed by Himyar until the deathblow was finally dealt by Hadramawt ca. 150-160. In the 220s, however, the western part of Hadramawt was attacked by Saba'. Although a Hadramī regime managed to survive, Saba' and Himyar were the only South Arabian polities with which the Aksumites are known to have had direct relations. Throughout the 3 rd century, down to the eventual conquest of Saba' by Himyar ca. 275, the Aksumites allied themselves alternately with one or other of these two polities depending on the political climate of the time, ${ }^{20}$ all the while seeking to establish a sphere of influence in the Tihāma region, the "wild west" of South Arabia, referred to in Sabaic inscriptions by the name Sahrat ${ }^{\text {ann }}$. A poor and relatively peripheral region, much of the Tihāma, apart from Red Sea ports in the south like al-Mukhā' (controlled by Himyar), lay beyond the direct rule of either Saba' or Himyar. As late as the first half of the 4 th century, the Himyarites, despite having by then overcome all remaining pockets of resistance in Hadramawt, ${ }^{21}$ were obliged to undertake military operations against the Tihāma. ${ }^{22}$ Here, too, the Aksumites established alliances with local tribes like 'Akk ${ }^{\mathrm{um}}$ and Dhü-Sahrat ${ }^{\mathrm{im}}$, often acting in concert with these groups against Saba' or Himyar.

Exactly why the Aksumites chose to involve themselves in the political affairs of South Arabia at the time they did is not a question that can be easily answered. There are, however, indications that the Romans established some sort of sphere of influence in South Arabia at the end of the 1st century B.C.E, and even posted troops there. ${ }^{23}$ From two Latin inscriptions in the Farasān Archipelago, one dating from ca. 120, the other from 143-144, it is known that a Roman legionary detachment was stationed there during the 2nd century, most likely to protect shipping lanes against pirates. ${ }^{24}$ What exactly happened after the mid-2nd century is not clear, owing to lack of evidence. Not long after the record of the Roman presence in the southern Red Sea falls silent, we find the earliest known reference to the Aksumites in South Arabia in Robin-Umm Laylā 1, a Sabaic inscription dating from ca. $160-190 .{ }^{25}$ By this time, so the inscription tells us, the Aksumites already penetrated the Yemeni highlands and had started threatening the local tribes, who in response formed an alliance for mutual protection. If it is true that the Romans withdrew their military forces

20 Still useful as a summary of Aksumite activities in South Arabia during the 3rd century is Robin, "Intervention abyssine".

21 Robin, "Hiimyar au ive siècle".

22 'Abadān 1/5.24-7 (Müller, Sabäische Inschriften, pp. 51; 52).

23 Speidel, "Almaqah".

24 Speidel, "Außerhalb des Reiches".

25 Robin-Umm Laylā 1/1-6 (Robin, "Saba' et la Khawlān", p. 18). 
from South Arabia after the mid-2nd century, the Aksumites might have sought to take advantage of the situation by seeking to establish a sphere of influence of their own in the region. What Robin-Umm Laylā 1 does not explain is how the Aksumites had gotten this far this early. One would assume that they could only have reached the Yemeni highlands having already established some base on the Red Sea coast, though it is not clear whether any significant number of Aksumites had settled permanently in South Arabia at this time. The earliest epigraphic evidence to that effect appears in the mid-3rd century.

\subsection{Sabaean Relations with Aksum under 'İlsharah Yahdub and Ya'zil Bayyin}

A number of important Sabaic inscriptions documenting the Aksumite conflict with Saba' date from the coregency of the Sabaean king 'İlsharah Yahdub and his brother Ya'zil Bayyin (r. ca. 245-26o). Of these, several allude to Aksumite settlements in the Tihāma region ('s $\left.{ }^{\prime} d\right)$. The relevant inscriptions all come from the Sabaean capital of Mārib.

\subsection{1 $\quad$ Ir 69}

One of the inscriptions in question, Ir 69, was dedicated at the Bar ${ }^{\text {ann }}$ Temple by three officers of the royal brothers, Wahab'awwā ${ }^{-m}$ Yi'dhaf, and Khadhwat and Karib'athat 'As'ad. According to the text:

ḍb' mr’y-hmw 'ls² rḥ Yḥ̣b w-'hyy-hw Y’zl Byn mlky S'b' w-D-Rydn b- ly 'ș̣d

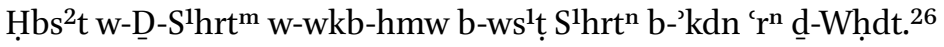

Their two lords, 'İlsharah Yaḥ̣ub and his brother Ya'zil Bayyin, the two kings of Saba' and Dhū-Raydān, waged war against the villages of the Ethiopians and Dhü-Saharat ${ }^{\mathrm{im}}$, and they came upon them in the middle of Sahrat ${ }^{\text {ann }}$ in the foothills of the mountain of Wahdat.

A few lines later in the same inscription, we read that:

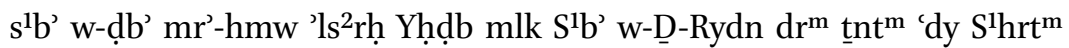

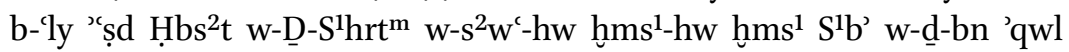

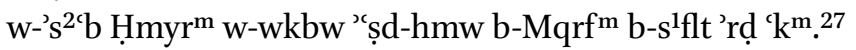

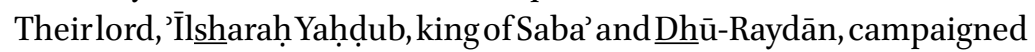
and waged war a second time against the villages of the Ethiopians and

26 Ir 69/20-24 (Bron, “Nouvelle inscription sabéenne", pp. 79; 80).

27 Ir 69/27-32 (Bron, ibid.). 
Dhü-Sahrat ${ }^{\mathrm{im}}$, and his main army division, the army division of Saba', and some of (those armed divisions) of the triballeaders and tribes of Himyarum served under him, and they came upon their villages in Maqrafum on the plain of the land of 'Akk ${ }^{\mathrm{um}}$.

Two points are worthy of note here. One is that no distinction is made between the villages inhabited by the Ethiopians $\left(H b s^{2} t\right)$ and those inhabited by the indigenous Tihāma tribe of Dhū-Sahrat ${ }^{\mathrm{im}}$. Whether this means that both groups inhabited the same settlements is difficult to say for lack of further details, though the fact that the term used for village is of Ge'ez derivation suggests that those settlements designated as 'ș $d$ were established by the Aksumites, even if they came in time to attract indigenous peoples. Significantly, when the origins of the inhabitants of the "ss d are given, Ethiopians are invariably among said inhabitants, and in fact Ja 574, another inscription, which we shall examine in greater detail shortly, ${ }^{28}$ links one group of "ṣd exclusively with the Ethiopians, with no reference to tribes from the Tihāma. Contrasted with villages of this type are settlements designated $q r$, 'dwr, and 'dyr in Sabaic. Although such settlements, as we shall see below, are at times associated with Aksumites together with local tribes, the terms used to designate them, while absent from Ge'ez, are attested in Arabic, e.g. qarya "village" and dār "territory, domain". Perhaps, then, those settlements designated $q r$, 'dwr, or 'dyr were villages established by the indigenous peoples of the Tihāma at which Aksumites later took up residence.

\subsubsection{Ja 575}

The attack on the Ethiopians at the mountain of Wahdat is documented another inscription, Ja 575, dedicated at the 'Awwa ${ }^{\mathrm{m}}$ Temple by several members of the tribe of Sukhaymum, the names of whom are not preserved. In this inscription, we are told that:

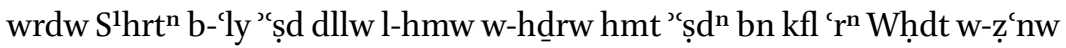

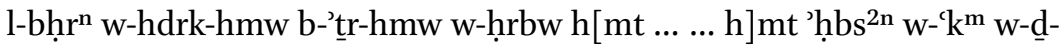

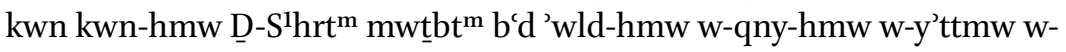
tqdmn w-rtḍhn b-'m hmt 'ḥbs ${ }^{2 n}$ w-[...... w-'] wld-hmw w-"nt-hmw f-hrgw

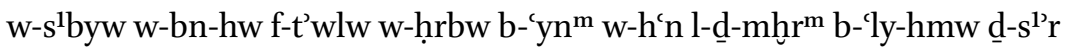

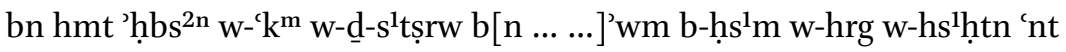

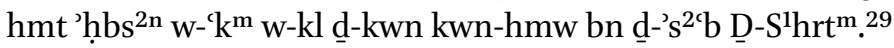

\footnotetext{
$28 \quad \S 3.1 \cdot 3$.

29 Ja 575/4-7 (Jamme, Sabaean Inscriptions, p. 64).
} 
They (i.e. members of Sukhaym ${ }^{\text {um }}$ ) descended upon Sahrat ${ }^{\text {ann }}$, against the villages about which they had been informed. And they threatened those villages from the flank of the mountain of Wahdat. And they shifted their position to the seacoast and followed them (i.e. the enemy) by their tracks. And they made war on th[ose ... ... th] ose Ethiopians and 'Akk um and those who supported them among Dhü-Sahrat ${ }^{\mathrm{im}}$, the sedentary folk, after their children and their possessions. And they regrouped and fought and did battle with those Ethiopians and [..... And] their children and their wives were killed or taken prisoner. And from there they returned. And they made war at 'Ayn ${ }^{\text {um }}$ and those who remained of those Ethiopians and 'Akk ${ }^{\mathrm{um}}$ and those who had sought help fr[om ......] mounted an attack against them on the following day [...] with a decisive defeat and a killing and a routing of a contingent of those Ethiopians and 'Akk ${ }^{\mathrm{um}}$ and all those who supported them among Dhü-Sahrat ${ }^{\mathrm{im}}$.

Although Ja 575 provides a few details not given in Ir 69, it sheds no light on the question of Aksumite settlement patterns in South Arabia. Once again, the Aksumites are said to have operated in concert with the local tribes of 'Akk ${ }^{\text {um }}$ and $\underline{\text { Dhu}}$-Sahrat ${ }^{\mathrm{im}}$. Perhaps significantly, each time the coalition is mentioned, the lists of its constituent elements are invariably headed by the Ethiopians $\left(' h b s^{2 n}\right)$, while Dhū-Sahratim —and even then, so it appears, only some of them-merely provided support of an undisclosed nature. This suggests that the resistance movement in the Tihāma was led by the Aksumites, perhaps attracted to the region because local tribes had sought out their aid in the struggle against the Sabaean state. In the 6th century, disenfranchised elements in South Arabian society would again seek military aid from Aksum, ${ }^{30}$ and while they were prompted to do so by primarily religious - rather than politicalfactors, it is not implausible that, already in the 3 rd century, marginalized groups in the Tihāma saw in Aksum a powerful ally. One final point connected with the portion of text presented above that bears mentioning are the references to women and children among those groups whom the Sabaeans attacked. Despite the lacunae in the inscription and the somewhat ambiguous wording of what text survives, it is likely that the women and children in question were affiliated with all three groups in the coalition, rather than with the Aksumites alone. Insofar as the Aksumites are concerned, two scenarios are possible. One is that the Aksumite soldiers brought their families with them, in which case it would seem that they planned to settle permanently in the Tihāma. Alternatively, such soldiers might have married local women-a not implausible scenario if, as suggested above, Aksumites and local tribal groups

On this, see $§ 5.1$. 
occupied the same settlements. In fact, both the relocation of Ethiopian families and marriage with local women are likely to have occurred.

3.1.3 Ja 574

Another relevant inscription from the 'Awwa ${ }^{-m}$ Temple, Ja 574 , is dedicated by 'İlsharah Yahdub and his brother Ya'zil Bayyin themselves and claims that the Sabaean god 'Îlmuquh intervened in Sabaean military operations against the Aksumites.

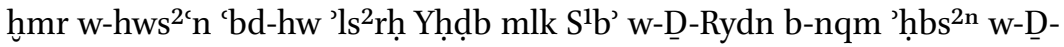

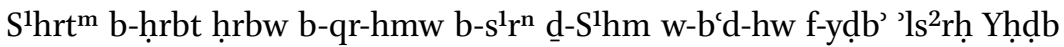

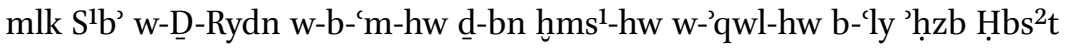

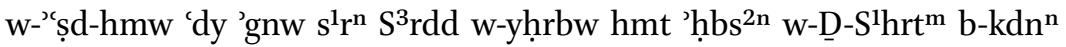

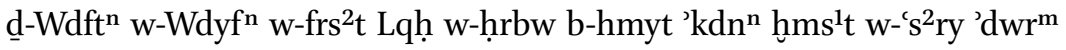

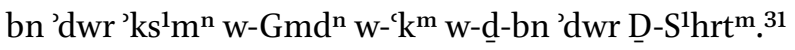

He (i.e. 'Îlmuquh) bestowed upon and granted to his servant 'Îlsharah Yahḍub, King of Saba' and Dhū-Raydān, the punishment of the Ethiopians and Dhü-Sahrat ${ }^{i m}$ in a battle which they waged in their village(s) in the valley of Sihām. And after that, 'İlsharah Yaḥ̣ub, King of Saba' and Dhū-Raydān, and with him some of his main army and his tribal leaders, waged war against the armed bands of the Ethiopians and their villages, up to the cultivated area of the valley of Surdud. And they made war on those Ethiopians and Dhū-Sahrat ${ }^{\mathrm{im}}$ at the hill of Wadfat ${ }^{\text {tan }}$ and (at) Wadayf ${ }^{\text {an }}$ and (at) the cultivated field of Liqah. And in those hills they made war on twenty-five villages among the villages of the Aksumites and Gumd ${ }^{\text {an }}$ and 'Akk ${ }^{\text {um }}$, and some of the villages of Dhü-Sahrat ${ }^{\text {im }}$.

As with those villages designated "s $s$ in Ir 69 and Ja 575 , the villages referred to as ' $d w r$ are associated with Ethiopians, here designated specifically as Aksumites $\left({ }^{\prime} k s^{l} m^{n}\right)$, as well as with local tribes. In this instance a new group, Gumd $^{\text {an }}$, joins the ranks with the by now familiar 'Akk ${ }^{\text {um }}$ and Dhü-Sahrat ${ }^{\text {imm }}$. Nothing is said of the families of the Aksumites, however, though Gumd ${ }^{\text {an }}$ is said to have sent a delegation to Șan'a' - at that time a secondary capital of Saba' - where they gave their children as hostages $\left(w h b w^{\prime} w l d-h m w^{\prime} w t q^{m}\right) .{ }^{32}$

31 Ja 574/3-8 (Jamme, Sabaean Inscriptions, p. 6o).

32 Ja 574/10-11 (Jamme, Sabaean Inscriptions, pp. 60-61). 


\subsection{Himyarite Conflict with Aksum}

Our final text that refers to Aksumite settlement in the Tihāma, MAFRAY-alMi'sāl 5, is a Sabaic inscription from al-Mi'sāl in southwestern Yemen, dating from the reign of the Himyarite king Yāsirum Yuhan'im (ca. 265-287). Dedicated in honor of the sun-goddess 'Âliyat by a military leader named Haziyy ${ }^{\text {an }}$ 'Awkan, the inscription documents a military conflict that affected Aksum at the highest level.

wqh-hmw mr'-hmw Ys ${ }^{1} \mathrm{r}^{\mathrm{m}}$ Yhn'm mlk S'b' w-D-Rydn b-ywm 'dyw mlky

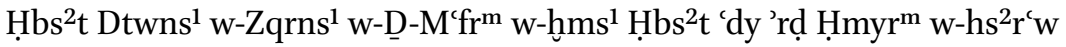

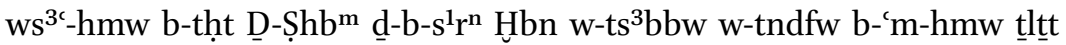

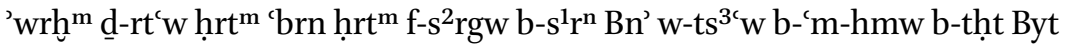
d-'rtt w-ts'bțw b-'m-hmw w-s'bțw-hmw 'dy h'dyw-hmw hrt-hmw b-s' ${ }^{1}$ t $^{\mathrm{m}}$ w-qlmw d-hb bn mqtwt w-'rgl mlk ${ }^{\mathrm{n}}$ w-mns ${ }^{3} \mathrm{rt}^{\mathrm{n}}$ d-b-'m-hmw. ${ }^{33}$

Their lord, Yāsirum Yuhan'im, King of Saba' and Dhū-Raydān, commanded them on the day when the two kings of the Ethiopians, Datwanas and Zaqarnas and Dhü-Macāfirim and the main army of the Ethiopians advanced into the land of Himyarum and they prepared to fight them below Dhū-Ṣuhab ${ }^{\text {im }}$, which is in the valley of Khubān. ${ }^{34}$ And they engaged, and exchanged arrow-fire, with them for three months, (during) which they set up one camp against the other. Then they gathered in the valley of Bana' and they (i.e. the Himyarites) engaged in battle with them below Bayt Dhū-'Arta' and fought with them and beat them back until they caused them to fall back to their camp with a routing. And they cut off those who had acted unjustly against the lieutenants and infantry of the king and the vanguard that was with them.

That this was a major conflict is evident from the fact that two Aksumite kings, most likely coregents, got involved. ${ }^{35}$ As before, the Aksumites allied them-

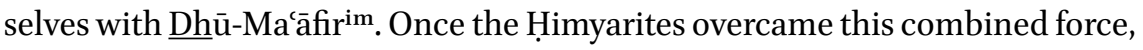
they pursued what remained of the Aksumite force, together with several local tribes that stood in their way.

33 MAFRAY-al-Mi'sāl 5/9-11 (Müller, Sabäische Inschriften, pp. 29-30).

34 This can be identified with Wādī Khubān, located to the east of Zafār.

35 The vocalization of the names Datwanas and Zaqarnas is hypothetical. That the individuals bearing this name were indeed reigning monarchs rather than simply the sons of kings is evident from the fact that other Sabaic inscriptions specifically designate other individuals as sons of the Aksumite king ( $\left.w l d n g s^{2} y^{n}\right)$. For attestations of this phrase, see Ja 576+Ja 577/19.22 (Jamme, Sabaean Inscriptions, pp. 77; 78 [line 3]); Ja 631/21 (Jamme, ibid., pp. 132; 133). 


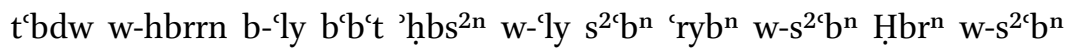
Yhgmn w-wḍ'-hmw w-hs'b'n w-'wlw kl 'qdm-hmw w-'wțq-hmw w-'wlw $s^{3}$ d'n-hmw w-mdd-hmw w-s ${ }^{2} b^{n}$ Yhgmn f-cdyw b-hyl-hmw w-'dyw w-hbln w-dhr kl mṣnc-hmw hums ${ }^{1}$ mșn $^{\mathrm{cm}}$ w-kl 'lwd-hmw w-bnt-hmw w-'qny-hmw w-'ș̣d-hmw. ${ }^{36}$

They brought to submission and went forth against the roaming bands of Ethiopians and the tribe of 'Arīban and the tribe of Hubr ${ }^{a \bar{a}}$ and the tribe of Yuhgamin, and they humiliated them and forced their capitulation. And they brought back all of their leaders and hostages. And they brought back their comrades-in-arms and their military aids and (members of) the tribe of Yuhagmin. Then they advanced and plundered and burned all of their forts - five forts (in total) - and (seized) all of their sons and their daughters and their possessions and their villages.

As with the other inscriptions which we have examined thus far, it is not possible to determine what portion of those taken captive were Aksumites. Judging from the reference to "ss $d$, however, it is likely that the Aksumites were represented among the prisoners-of-war. That children were taken captive indicates that some of the Aksumites had started families in South Arabia, whether with Ethiopian spouses who might have accompanied them to their new home or with local women. MAFRAY-al-Mi'sāl 5 , it should also be noted, contains the last known 3rd-century reference to the Aksumite presence in South Arabia. Although Himyar maintained relations with Aksum during the 4th century, as we shall see shortly, ${ }^{37}$ it is not until the early 6 th century that we again find allusions in Sabaic inscriptions to Aksumite settlement in South Arabia. This suggests that Yãsirum Yuhan'im was the ruler who succeeded in expelling the Aksumites from South Arabia.

\subsection{Aksumites in Peripheral Areas of South Arabia}

Although the epigraphic material analyzed thus far indicates Aksumite settlement only in the Tihāma during the 3rd century, there are hints of an Aksumite presence in other, more peripheral, parts of South Arabia during the same period.

\subsubsection{Ja $576+$ Ja 577}

One indication of this is a passage in Ja $576+\mathrm{Ja} 577$, a Sabaic inscription on two blocks of stone from the 'Awwām ${ }^{m}$ Temple at Mārib. Like most of the Sabaic inscriptions treated above, it, too, dates from the coregency of '̄ lsharah Yahḍub

36 MAFRAY-al-Mi'sāl 5/12-13 (Müller, Sabäische Inschriften, p. 30).

37 See $\S 4$. 
and Ya'zil Bayyin and, in fact, was dedicated by the two kings themselves. At one point, we are told that the people of Najrān, an oasis located north of the Yemeni highlands, had rebelled against Saba' and made common cause with the Aksumites. The latter had even appointed a governor over the town, supported by an armed contingent.

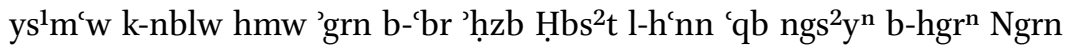
w-s ${ }^{2} b^{n}$ Ngrn w-hmw f-nz̧rw mw'd 'grn l-tzryn b-'br 'mr'-hmw 'mlk S'b' w-hhw-hw b-mw'd-hmw l-nșr 'nt 'ḥbs ${ }^{2 n} .38$

They (i.e. Sabaeans) had heard that those Najrānīs had sent a mission to the armed bands of the Ethiopians to aid the nagāś $\vec{\imath}$ governor in the town of Najrān and the tribe of Najrān. And they were aware of the (Ethiopians') promise to the Najrānīs to guarantee protection against their lords, the kings of Saba', but they thwarted it through (their knowledge of) their (i.e. the Najrānīs') promise to help the contingent of the Ethiopians.

There is much in this passage that remains obscure. If, however, one accepts the interpretation presented here, it would seem that the Aksumites had taken on the Najrānīs as vassals, hence the appointment of a governor who administered the town on behalf of the Aksumite king himself, but that the Sabaeans managed to intervene and reassert control. That this is what happened is evident a few lines later, where we read:

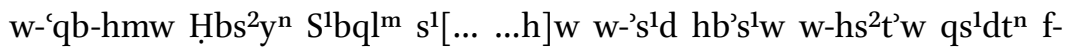
nblw b-'m-hw w-whbw bny-hmw w-bnt-hmw 'wțq ${ }^{\mathrm{m}}$ w-ḥmlw 'dy hgr'

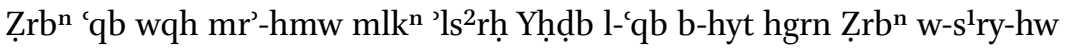
Ngrn. ${ }^{39}$

And as for their Ethiopian governor, Sabqal ${ }^{u m}[\ldots \ldots \mathrm{h}]$ is [...]. And those who had acted wrongfully and had staged the rebellion sent a mission with him and they gave their sons and their daughters as hostages. And they admitted into the town of Zirb ${ }^{\text {an }}$ a governor whom their lord, the king 'Îlsharah Yahḍub, commanded to govern in that town of Zirb ${ }^{\text {ann }}$ and their two valleys of Najrān.

Here the name of the Ethiopian governor is given, though the nature of his involvement in the events surrounding the reassertion of Sabaean control remain obscure, owing to the lacuna in the text. Regarding the place-names

$38 \quad$ Ja $576+$ Ja 577/26 (Jamme, Sabaean Inscriptions, p, 77 [line 10]).

39 Ja $576+$ Ja 577/28-29 (Jamme, Sabaean Inscriptions, p. 77 [lines 12-13]). 
mentioned in the text, the town of Zirb ${ }^{\text {ann }}$ is most likely to be identified with the site of al-Ukhdūd, ${ }^{40}$ located not far from the town of Najrān. The latter had given its name to the valley in which both towns were located. In view of the presence of an Ethiopian governor and an armed force of Ethiopians at Najrān, it is clear that the oasis had a community of Aksumite expatriates during the mid-3rd century. That Sabqalum is referred to as "the nagāsis 's governor" ('qb $\left.n g s^{2} y^{n}\right)$ nagāsí being the title for king in Ge'ez indicates that this community was essentially there to maintain Aksumite control, albeit in the guise of aiding the Najrānīs against the Sabaeans. How long the Aksumite occupation of Najrān lasted is hard to say, though there is nothing in Ja $576+\mathrm{Ja} 577$ to suggest a timeframe of more than at most a few years. Those said to have "acted wrongfully and had staged the rebellion" $\left(h b^{3} s^{l} w w-h s^{2} t^{\prime} w q s^{l} d t^{n}\right)$ were probably the Najrānīs. The Aksumites gave aid to the effort and even occupied Najrān, but since they were not Sabaean subjects, they cannot be said to have rebelled against Saba', only to have supported those who did. As a result, it is likely that the sons and daughters who were handed over as hostages were the children of local Najrānīs, not Aksumites, though the possibility that at least some of these children were the offspring of local women by Aksumite troops cannot be dismissed.

\subsubsection{Ge' Grez Graffiti from the Grotto of Ḥō (Soqoțrā)}

To date, the only trace that the Aksumites themselves have left of their presence in South Arabia comes not from the mainland but from the island of Soqoțrā. The Periplus of the Erythraean Sea refers to the island as Dioskouridēs

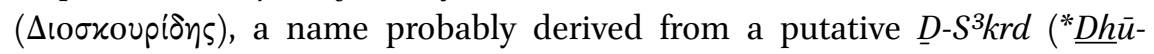
Sakürid), ${ }^{41}$ and reports that it was a colony of the kingdom of Hadramawt and was populated by a mixture of Arabs (i.e. South Arabians), Indians, and Greeks who had gone there to trade. ${ }^{42}$ This statement is confirmed by the discovery of Roman, Haḍramī and Indian pottery on Soqoțrā. ${ }^{43}$ Although the Periplus says nothing about an Aksumite presence on the island, a Belgian team of speleologists exploring the grotto of Ḥōq at the northern end of Soqoțrā between December 2000 and January 2001 came across a series of inscriptions and graffiti in not only Palmyrene, Ancient South Arabian, Sanskrit, and Middle Indic, but also Ge'ez. Given the timeframe for the corpus, it is clear that the Ge'ez graffiti are of Aksumite date. To be sure, only six Ge'ez graffiti can be confidently identified, together with two that are probably Ge'ez and three that could be either

\footnotetext{
40 Schiettecatte, "Najrān”, pp. 28-29.

41 Robin 2012: 445.

42 Casson, Periplus, §30.10.9-11.

43 Biedermann, Soqotra, p. 33.
} 
Ge'ez or Ancient South Arabian. ${ }^{44}$ Needless to say, this is not a significant number, particularly when compared to the 193 Indian graffiti and inscriptions, which make up the majority of the corpus. Nevertheless, it does indicate that Aksumites were present on Soqotrā. To focus just on the six definitively Ge'ez graffiti, three appear to be of Christian origin and shall be treated below, ${ }^{45}$ while the other three may well date from an earlier period, most probably the 3rd century, when Aksumite influence on mainland South Arabia was at its height. However, as we shall see in the following section, there is evidence of continued Aksumite commerce with South Arabia during the 4th century, in which case Aksumite visits to Soqoțā at that time are also conceivable. Of the three pre-Christian graffiti, two consist of what are probably names: 'Artah $(' r t h)^{46}$ and Səmūr/Samr $(\operatorname{Sm}[r]) \cdot{ }^{47}$ The other reads ['] hff'ygns[ []t[s'],${ }^{48}$ of which no sense can be made. Although the Periplus alludes to foreign settlers on Soqoțrā, there is no hard evidence that the individuals - whatever their origin - who left written records of their visits to Hōq were permanent residents, and it is likely that this applies to the Aksumites as well. It remains unknown what relationship the Aksumite visitors to the island had with other foreigners, as well as with the indigenous inhabitants.

Aksumite Relations with South Arabia in the 4th Century

Following the withdrawal of Aksumite military forces from South Arabia after ca. 270, the kings of Aksum, in particular Ousanas (r. ca. 310-330) and his brother and successor 'Ẽzānā (r. ca. 330-370), continued to lay claim to South Arabia in their royal titles, which designate as vassals of Aksum both Himyar and the by now defunct kingdom of Saba', as well as their respective capitals of Zafär and Mārib. The latter are alluded to by the names of their respective royal palaces: Raydān at Zafār and Salhịn at Mārib. These claims of dominion over South Arabia are political fictions through and through, ${ }^{49}$ but nevertheless indicate that the memory of past Aksumite occupation of South Arabia retained a certain degree of ideological importance for the kings of Aksum.

It must be emphasized, however, that the cessation of Aksumite occupation in South Arabia in no way implies a cutting of ties between Aksum and Ḥimyar,

\footnotetext{
44 Robin, "Sudarabiques et Aksūmite", p. 439.

45 See $\$ 5 \cdot 4 \cdot 4$.

46 Graffito 2:20 (Robin in Strauch, "Catalogue”, pp. 48-49).

47 Graffito 2:31 (Robin in Strauch, "Catalogue”, p. 6o).

48 Graffito 2:30 (Robin in Strauch, "Catalogue", p. 59).

49 Hatke, Aksum and Nubia, pp. 68-69 [n. 276].
} 
by now the unquestioned superpower in South Arabia. For one thing, Himyar maintained diplomatic ties with Aksum during the 4th century, as we learn from a Sabaic inscription from Mārib (Ir 28) documenting a diplomatic mission to Aksum dispatched by the Himyarite king Karib’il Watar Yuhan'im (r. ca. 312-316) under the leadership of one Sharah'athat 'Ashwa' Dhü-Hubāb. The Aksumites responded with a mission of their own, led by two diplomats named 'Ahẹequm $\left(' h[y] q^{m}\right)$ and Zalnas $\left(Z \ln s^{I}\right)$ respectively. ${ }^{50}$ Archaeology also yields evidence of Aksumite contact with Himyar during the 4 th century. For this, we turn to Qāni', a port founded by the kingdom of Hadramawt towards the ist century B.C.E some $100 \mathrm{~km}$ southwest of al-Mukallā. After the fall of Hadrramawt, Qāni' continued to serve as South Arabia's chief important outlet to the Indian Ocean. Towards the end of the so-called Middle Period (BA-II), Aksumite ceramics appear for the first time at the site. ${ }^{51}$ Since the Middle Period at Qāni' has been dated to the 2nd to 5 th century, the appearance of such ceramics can be dated to sometime not earlier than the 4th century. Sherds similar to, and possibly to be identified with, Red Aksumite Ware and Gray and Black Aksumite Ware have been also been found at Qāni'. ${ }^{52}$

\section{$5 \quad$ Aksumite Relations with South Arabia in the 6th Century}

The 6th century witnessed a renewal of Aksumite military intervention in South Arabia. Yet the nature of this intervention differed considerably from that of Aksumite intervention during the 2nd and 3rd centuries. Whereas in earlier centuries the Aksumites had for the most part occupied relatively peripheral regions in South Arabia and had formed alliances with such regional powers as were deemed political useful, their intervention in the early 6th century was far more organized and systematic and was driven by a much clearer agenda. This second period of intervention in South Arabia is characterized by a policy of appointing sympathetic Christian members of the local elite to rule Himyar on behalf of Aksum, supported by Aksumite troops and a cadre of Aksumite officials. Ostensibly, Aksum's intervention in the early 6th century

50 Ir 28 (al-Iryānī, Fı Tảrīḳh al-Yaman, p. 147). In his transcription of the inscription, al-Iryānī divides the text into two sections but does not indicate the divisions between the lines of text as they would have appeared in the original inscription. As with the names of Kings Datwanas and Zaqarnas in MAFRAY-al-Mi'sāl 5 , the vocalization of the names of the Aksumite diplomats is hypothetical. For a discussion of their names, see Müller, "Abessinier", pp. ${ }^{163-164 . ~}$

51 Sedov, "Stratigraphy and Development", p. 375.

52 Sedov, "Synagogue”, p. 107 (Fig. 46/442, 444-445), 110. 
was prompted by the persecution of Christians - specifically Christians of the Miaphysite sect to which the Aksumites belonged ${ }^{53}$ — by Jewish Himyarites. While it might well have been the case that the Aksumites simply used this bout of persecution as a pretext for establishing a sphere of political influence in South Arabia, the evidence from the Ge'ez records left by the Aksumitesnot to mention the Syriac and Greek sources that document South Arabian affairs in the 6th century — present this period of Aksumite intervention in unabashedly religious terms. ${ }^{54}$

\subsection{Historical Background}

While some details remain obscure, the general course of events in 6th-century South Arabia is reasonably clear. During the reign of the Himyarite king Marthad'il ${ }^{\text {an }}$ Yanūf (r. ca. 500-518?), the Aksumites seem to have established a diplomatic presence at the Himyarite capital of Zafār. ${ }^{55}$ Although some scholars have gone so far as to posit that Marthad'îlān Yanūf was actually brought to power by the Aksumites, ${ }^{56}$ the extant documentation for his reign does not yield any concrete data bearing on the manner in which he came to the throne. ${ }^{57}$ If the presence of Aksumite diplomats at Zafār indicates amicable relations between Aksum and Himyar-whatever the religion of king Marthad'il ${ }^{\text {ann }}$ Yanūf might have been-this state of affairs seems not to have lasted for long, for at some point during the second decade of the 6th century a systematic persecution of South Arabia's Christian community was initiated. In response to this persecution, the Aksumite king Kālēb (r. ca. 510-540) dispatched a punitive campaign to South Arabian under the command of a Himyarite named Ḥayyān ca. $518 .{ }^{58}$ In the process, the Aksumites brought to

53 Nestorians, the other major Christian sect represented in South Arabia, appear to have not only been left alone during the persecutions, but are even charged in Miaphysite sources with having acted as collaborators with Himyarite Jews in the persecutions (Arzhanov, "Zeugnisse").

54 For a detailed discussion, see Hatke, Africans in Arabia Felix. Although the corpus of 6thcentury Ge'ez inscriptions found in Yemen (Hatke, ibid., pp. 355-384; Müller, "Äthiopische Inschriftenfragmente", passim) implies the presence of Aksumites in Himyar, they have been omitted from the present study on the grounds that, in terms of their actual content, they yield little or no information about Aksumite settlement in South Arabia.

55 See $\S 4$.

56 Robin, "Himyar et Israël", pp. 871; 873.

57 That Marthad'īla ${ }^{\text {lan }}$ Yanūf did not come to power through royal succession is evident from the fact that he never bears a patronym, as all Ḥimyarite rulers born of a king were in the habit of doing.

$5^{8}$ Moberg, Book of the Himyarites, p. $3^{\mathrm{b}}$ (Syriac text). This individual's name appears in the form Hywn' in the Syriac text. He is most likely to be identified with the Hyn who, according to Kālēb's victory inscription from Aksum, RIÉth 191/35 (Drewes/Schneider, 
power a Himyarite Christian named Ma'dikkarib Ya'fur. Although this king managed to establish a degree of stability in South Arabia and embarked on a campaign of military expansion into Central and North Arabia that took Himyarite troops as far as central Mesopotamia, ${ }^{59}$ his reign was brought to an abrupt end ca. 522, when the Himyarite Jewish rebel Yūsuf 'As'ar Yath’ar declared himself king and reinitiated the persecution of South Arabia's Christians. The first target in Yūsuf's campaign was the Aksumite community in Zafār, after which the Christians of the Tihāma were attacked. ${ }^{60}$ Then, after the Tihāma was fortified as a precaution against Aksumite incursions, Najrān was besieged and its Christian inhabitants were given the choice of converting to Judaism or the sword. When most of Najrān's Christians refused to recant their faith, they were slaughtered en masse by Yūsuf's forces. In response to these aggressions, Kālēb invaded South Arabia once more in 525, this time leading the invasion force in person. Following his defeat of Yūsuf, Kālēb set about restoring those churches that had been destroyed in the conflict and welcoming back within the fold those Christians who had converted to Judaism under duress, after which he placed another South Arabian Christian, Sumūyafa' 'Ashwa', on the Himyarite throne.

However, as before, the reign of this Aksumite vassal was not to last long, for at some point between $53^{1}$ and 540 a new potentate came to power-not a Himyarite Jew this time but in fact a Christian Ethiopian general in the Aksumite army named 'Abrəhā, who had come to South Arabia during the invasion in 525 and had stayed on, rising through the ranks until he seized power and declared himself an autonomous king of Himyar. After two punitive campaigns sent by Kālēb failed to remove 'Abrəhā from power, Aksum begrudgingly accepted his rule over Himyar on condition that he paid tribute. ${ }^{61}$ While there is no indication as to how long he maintained his end of the bargain, 'Abrəhā maintained diplomatic relations with Aksum, as well as with the Romans and the Sāsānids, as well as with the Ghassānids and the Lakhmids, who were clients of the Romans and Sāsānids respectively. ${ }^{62}$ Like Ma'dīkarib Yacfur, 'Abrəhā undertook a program of military expansion in the Arabian Peninsula, and managed to extend Himyar's sphere of political influence as far as the oasis of al-Hufüf in East Arabia and the frontier of the Roman Empire in the

"Inscriptions guèzes", p. 273) had been sent by the king to Himyar with the Aksumite army. For a detailed discussion of Hayyān's identity, see Hatke, Africans in Arabia Felix, pp. 124-137.

59 Robin, "Royaume hujride", pp. 686-691.

6o See below.

61 Procopius, History of the Wars, trans. Dewing, §1.20.8.

62 CIH 541/87-92 (Müller, Sabäische Inschriften, p. 115). 
north. ${ }^{63}$ Yet under the brief, ineffectual reigns of his sons Yaksūm (r. ca. 56o$5^{65}$ ) and Masrūq (r. ca. 565-570) this pan-Arabian empire quickly crumbled, and South Arabia was itself conquered by the Sāsānids in the 570 s. ${ }^{64}$

\subsection{Gar antichità $9 \mathrm{~d}$}

Our first text pertaining to the Aksumite presence in 6th-century South Arabia is the Sabaic inscription Gar antichità $9 \mathrm{~d}$. Originally erected at the Himyarite capital of Zafār, it was moved at some point to Bayt al-Ashwāl, where it was reused in the structure of a modern house. The text reads as follows:

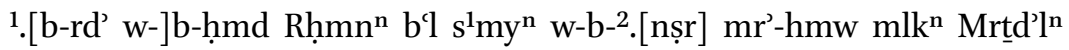

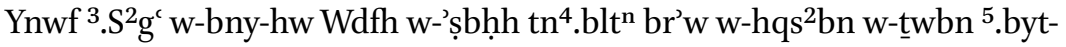

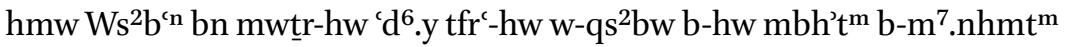

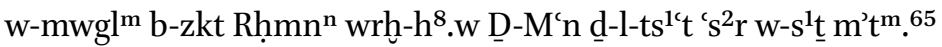

1.[With the aid of, and] with praise to, Rahmāna ${ }^{\text {an }}$, Lord of Heaven, and

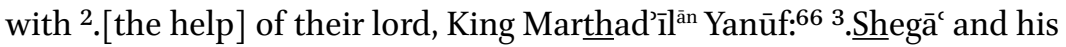
sons Wadfā and 'Așbehā, the am ${ }^{4}$.bassadors, built, completed, and renovated ${ }^{5}$.their house of Washba an from its foundations to ${ }^{6}$.its roof, and finished off therein the entrance with polished $\mathrm{ma}^{7}$.sonry and alabaster, by the grace of Rahmāna ${ }^{\text {ann; }}$ the month ${ }^{8}$.of Dhū-Macūn of 619 (of the Himyarite Era=March 509).

Since the dedicants of this inscription are described as "ambassadors" (tnblt), it is clear that they had come from abroad. ${ }^{67}$ Müller identifies their names as Ethiopian, ${ }^{68}$ in which case we can assume that they came from Aksum.

63 Robin/Ṭayrān, "Soixante-dix ans".

64 See $\S 6$.

65 Müller, Sabäische Inschriften, p. 92.

66 Here, the use of "lord" ( $\left.m r^{\prime}\right)$ in reference to Marthad'îlan Yanüf should be understood as a term of respect rather than an expression of political submission. This is paralleled elsewhere in the South Arabian epigraphic corpus by instances in which foreigners dedicating an inscription will invoke the local ruler as "lord". Thus in RES 2999, a Minaic inscription from Barāqish (ancient Yathill), the dedicant, Yishrah'īl bin 'Albä’, himself a Minaean, invokes the names of the Minaean king Waqah'îl Yitha' and his son and coregent 'îlyafac Yishūr, as well as the name of the Qatabānian king Shahr Yagill Yuhargib, referring to all three as "lord" (Robin, "Royaume de Ma'īn", pp. 180-181). Similarly, Ja 931, a Ḥadramitic inscription from al-'Uqla (ancient 'Anwādum) dedicated by a group of foreign envoys hailing from Palmyra, Chaldaea, and India, invokes the Ḥaḍramī king 'Îlī'azz Yaluț, referring to him as "their lord" ( $m r^{\prime}$-s $s^{l} m$ ) (Jamme, al-Uqlah Texts, pp. 44-45).

67 For the sake of comparison, it bears mentioning that the Sāsānid diplomatic mission which 'Abrəhā had received in the 540 is is referred to as tnblt mlk Frs' "the ambassadors of the king of Persia" in Cı H 541/89-9o (Müller, Sabäische Inschriften, p. 115).

Müller, "Abessinier", pp. 163-164. 
Although a number of Sabaic inscriptions dating from the $5^{\text {th }}$ and 6th centuries were dedicated by family groups ${ }^{69}$ nothing is said about the extended family (or families) of Shegā and his sons. It can hardly be doubted, however, that the residence which they built at Zafär was intended to accommodate wives and children as well.

\subsection{The Aksumite Invasion of 518}

The period between Marthad'îla ${ }^{\text {nn }}$ Yanūf's reign and the Aksumites' appointment of Ma'dīkarib Yacfur as king of Himyar remains obscure, though if the Syriac Book of the Himyarites is to be believed, it witnessed the persecution of South Arabia's Christian community by Himyarite Jews. Documentation for the Aksumite invasion of South Arabia in 518, which brought Madikkarib Yaffur to power, is similarly scant. The chapters that dealt with this invasion in the Book of the Himyarites are missing from the sole extant manuscript of the text and our knowledge that they existed at all is based solely on the surviving table of contents, while RIÉth 191, a Ge'ez inscription from Aksum dating from the reign of Kālēb, preserves only a very laconic mention of the invasion and says nothing of the settlement of Aksumites in South Arabia, nor even of the Aksumites' having brought Ma'dikkarib Ya'fur to power. ${ }^{70}$ Rather, it is in the far more abundant and detailed documentation of the Aksumite invasion of 525 that we find references to the presence of Aksumites in South Arabia at the time when Yūsuf seized power. It can be safely assumed that most members of this community settled in South Arabia following the invasion of 518 . They included a military contingent, presumably acting as an armed guard for Ma'dikarib Yafur, as well as religious leaders and no doubt administrators as well. From the number of Aksumite casualties of Yūsuf's agressions, as recorded in Syriac and Sabaic sources, it is even possible to gain a rough idea of the size of the Aksumite community of Zafār.

\subsection{The Aksumite Community in South Arabia in the Early 520 s}

The Martyrium Arethae, a 6th-century Greek text documenting Yūsuf's persecution of South Arabian Christians, is, while useful in many regards, not

69 These include inscriptions dedicated by men with their wives and children (Gar nuove iscrizioni 4; Ibrahim al-Hudayd 1; RES 5094); by a man with his wife, sons, and daughters (ZM $5+8+10)$; by a man with his brothers, his wife, and his children (RES 4109); and by a man with his mother, wife, and children, together with all of the members of his household ( $\mathrm{CIH} \mathrm{543).} \mathrm{For} \mathrm{the} \mathrm{full} \mathrm{text} \mathrm{of} \mathrm{these} \mathrm{inscriptions,} \mathrm{see} \mathrm{the} \mathrm{Corpus} \mathrm{of} \mathrm{Late} \mathrm{Sabaic} \mathrm{In-}$ scriptions in the University of Pisa's Digital Archive for the Study of Pre-Islamic Arabian Inscriptions (http://dasi.humnet.unipi.it/).

RIÉth 191/34-6 (Drewes/Schneider, "Inscriptions guèzes", p. 273). 
particularly helpful in terms of data on South Arabia's Aksumite community, as it states only that Yūsuf's forces killed all the men left by Kālēb in South Arabia, without furnishing any details. ${ }^{71}$ Instead, Syriac and Sabaic sources provide most of the information on the Aksumite presence in South Arabia following the invasion of 518 . It is to these sources that we now turn.

\subsubsection{Simeon of Bēth Arsham}

To begin with the Syriac sources, the Miaphysite bishop Simeon of Bēth Arsham (d. 540s) preserves a letter sent to the Lakhmid ruler al-Mundhir III (r. 503/5-554) from Yūsuf himself in the autumn of 523 . In it, the Himyarite king states that the attack on the Aksumites residing in South Arabia constituted the first stage in his anti-Christian campaign.

W-qadmāyat l-kūllhōn Kūšāyē da-ššīiīn (h)waw b-ațran d-nāțrīn (h)waw 'îttā hāy d-sabbar(w) (h)waw l-hōn da-bِnaw b-ațran eštaḳḥt d-ešaggeš w-elbūk ennōn w-qețlet l-kūllhōn d-hāwīn (h)waw mātēen wa-tmānēn gaḅē bِnay qyāmā w-ālmāyē. Hāy dēn 'ịdathōn 'ḅaḍtāh bēt knūštā dīlan. ${ }^{72}$

First I was able to throw into disorder and seize all those Ethiopians who remained in our country, who were guarding that church which they had published abroad that they had built in our country, and I killed them all, $28 \mathrm{o}$ men - monks and laymen. That church of theirs I converted into a synagogue for us.

Based on this passage, we can conclude that the Aksumite invasion of South Arabia in 518 was aimed at more than bringing the Christian Himyarite Macdikarib Yacfur to power, for the construction of a church in Himyar ${ }^{73}$ and presence there of Aksumite monks ( gabrē bnay qyāmā) indicates an effort to promote Christianity in the country. As for the resident Aksumite laymen ('âlmāye ), it is likely that this group included an armed contingent as well as administrators and advisers to Madikarib Yacfur. Although the text states that the monks and laymen together numbered 280 , it is quite possible that this number does not take into account the wives and children of the laymen, who

\footnotetext{
$71 \quad$ Martyrium Arethae §3.11-12.

72 Simeon of Bēth Arsham, Lettera, ed. and trans. Guidi, p. 2 (Syriac text).

73 The church alluded to in this passage might be the structure which Kālēb claims in RIÉth 191/35 to have built in Himyar (Drewes/Schneider, "Inscriptions guèzes", p. 273), though this is by no means certain. As we shall see below ( $\$ 5.4 \cdot 3)$, there was at least one other church associated with, and possibly built by, the Aksumites at the port of al-Mukhāa during this period.
} 
are more likely to have been taken prisoner than killed. The Book of the Himyarites and the Letter of Pseudo-Simeon of Bēth Arsham provide additional data, giving Abābūt as the name of the leader of the local Ethiopian community. ${ }^{74}$ Müller identifies this name with Old Amharic Abbabūt or Abbabat, a name which survives in Modern Amharic in the form Abbabačč. ${ }^{75}$ Although Yūsuf's letter does not specify where this massacre took place, the Letter of Pseudo-Simeon of Bēth Arsham notes that Abābūt was the archbishop of the

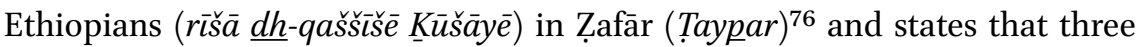

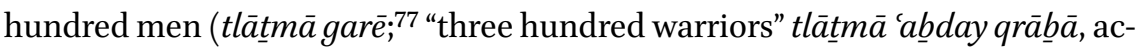
cording to the Book of the Himyarites ${ }^{78}$ ) accompanied him when he went forth to meet Yūsuf in person.

\subsubsection{Ry 508}

Further information on Yūsuf's attack on the Aksumites took place in Zafār is provided by Ry 508, a Sabaic inscription from the site of ān-Halkān 1 in the Jabal Kawkab region of southwestern Saudi Arabia, dating from June $5_{23}$ (DhūQiyāza $\bar{a}^{\mathrm{n}}$ in Year 633 of the Himyarite Era). In this inscription we read:

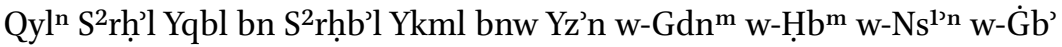

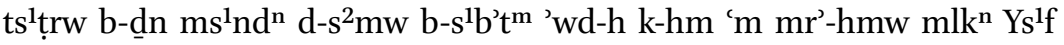

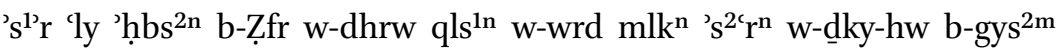
w-hurb Mhw ${ }^{\mathrm{n}}$ w-hrg ${ }^{4} \cdot \mathrm{kl}$ ḥwr-hw w-dhr qls ${ }^{1 \mathrm{n}} \cdot{ }^{79}$

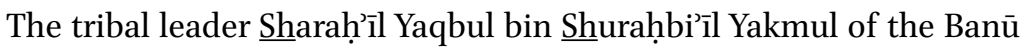
Yazan and the Gadan ${ }^{u m}$ and Habb ${ }^{u m}$ and Nasi ${ }^{a n}$ and Ghuba' wrote in this inscription, which they set up during the campaign against the Ethiopians in Zafär with which they were charged, when they were with their lord, the King Yüsuf 'As'ar. And they burned the church and the king came down to the 'Ash'ar (tribe) and sent him (i.e. Sharah'īl Yaqbul) with a detachment and he made war on Mukhāa $w^{a n}$ and he killed all of its inhabitants and he burned the church.

From this portion of the inscription we learn that the attack on the Aksumites in Zafär was followed by an attack on southwestern Yemen, targeting the port of al-Mukhäa' (Sabaic $\left.M h w^{n}{ }^{*} M u k h \bar{a} w^{a n}\right)$. Of the enemy forces, some 13,000 are

74 Moberg, Book of the Himyarites, p. 7a (Syriac text); Shahid, Martyrs, pp. iii-iv (Syriac text).

75 Müller, "Abessinier", p. 164.

76 Shahid, Martyrs, pp. iii-iv (Syriac text).

77 Shahid, Martyrs, ibid.

78 Moberg, Book of the Himyarites, p. 7a-b (Syriac text).

79 Ry 508/1-4 (Müller, Sabäische Inschriften, p. 98). 
said to have been slain and 9500 taken prisoner, ${ }^{80}$ though the inscription says nothing about how many of these enemies were Aksumite.

\subsubsection{Ry 507}

For further information on Yūsuf's military campaigns and the manner in which they affected the Aksumite community of South Arabia, we turn to Ry 507 from Bi'r Ḥimā, also located in southwestern Saudi Arabia and dating from July 523 (Dhū-Madhra ${ }^{\text {añ }}$ in Year 633 of the Ḥimyarite Era), which presents certain details relating to the activities of Yūsuf's forces not included in Ry 508 :

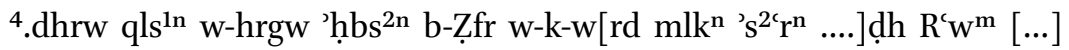

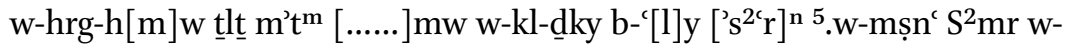
$\mathrm{Rkb}^{\mathrm{n}} \mathrm{w}-\mathrm{Rm}^{\mathrm{c}} \mathrm{w}-\mathrm{M}\left[\mathrm{hw}^{\mathrm{n}}\right.$...] bnh $[\ldots]$ ny w-mtw b-'s' ${ }^{2} \mathrm{r}\left[{ }^{\mathrm{n}}\right] \mathrm{w}-[\mathrm{dh}] \mathrm{rw}$ qls ${ }^{\mathrm{ln}} \mathrm{w}^{-}$ hrgw w-g் $[\mathrm{n}] \mathrm{mw}$ ['ḥbs $\left.{ }^{2 \mathrm{n}}\right]$ b-Mhw ${ }^{\mathrm{n}}$ b-[ḥw]r-hw Frs' ${ }^{1}$ nyt ${ }^{\mathrm{m}} .{ }^{81}$

${ }^{4}$.they burned the church and killed the Ethiopians in Zafār, and when the king ca[me down in force upon the 'Ash'ara ân ....] Ra'cw ${ }^{\text {um }}[\ldots]$ and he killed 300 of them [...]. And when he sent (an expedition) against ['A $\underline{\text { sh'ar }}]^{\text {ann }}$

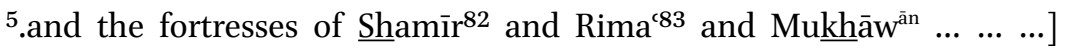
and they died in 'Ash'ar[ān]; and they [bur]ned the church and killed and plundered [the Ethiopians] in Mukhāa $w^{\text {ān }}$, together with its (other) [inhab] itants, the Farasān. ${ }^{84}$

Of particular interest here is the allusion to 300 enemy casualties. Although the identity of this enemy is obscured by the lacunae in the text, the number given here is close enough to the 280 Ethiopian monks and laymen whom Yūsuf boasts of killing in the letter quoted by Simeon of Bēth Arsham to suggest that they were Aksumites. Ry 507 is also of importance for the history of the Aksumite diaspora in South Arabia as it indicates that, in addition to Zafār, the Aksumites had by the early 6th century established a presence at the port of al-Mukhā', and that the town had a church, possibly built by the Aksumites. That al-Mukhā' attracted Aksumite settlers is undoubtedly due to the port's location on the Red Sea, which made it an ideal center for trade with Africa, as

\footnotetext{
$80 \quad$ Ry 508/5 (Müller, Sabäische Inschriften, p. 98).

81 Müller, Sabäische Inschriften, pp. 103-104.

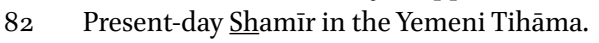

83 Rima' is regarded by al-Hamdānī as part of the territory of the 'Akk tribe (al-Hamdānī, Șifat jazirat al-'arab, ed. al-Ḥawālī, p. 107).

84 This tribe appears to have given its name to the Farasān Islands, located off the southern Red Sea coast of Saudi Arabia.
} 
indeed it was since at least the 1 st century. ${ }^{85}$ It is likely that many of the Aksumite residents of al-Mukhā' were merchants, as most of those resident at Qāni' are likely to have been. Since, however, Qāni' seems never to have been targeted by Yūsuf's campaigns, nor to have been directly affected by Kālēb's campaigns in South Arabia, its Aksumite community never merits mention in written sources. If ceramic evidence is any indication, the Aksumite community at Qāni' would seem to have passed its prime by the 6th century.

\subsection{Other Aksumite Communities in 6th-Century South Arabia}

Thus far, we have seen that there were Aksumite communities at both Zafār and al-Mukhā' during the early 6th century. What about elsewhere in South Arabia? As in the 3rd century, there is evidence of an Aksumite presence at Najrān as well as on Soqoțā. The Book of the Himyarites states that there was at least one Ethiopian deacon ( $m$ šamšānā) named Yōnan in residence at Najrān. ${ }^{86}$ He and several other foreign clergymen - two priests from the Lakhmid capital of al-Hīra in south-central Mesopotamia, a priest and a deacon of Roman origin, and a priest of Persian origin - are said to have been interrogated by Yūsuf during his occupation of Najrān. ${ }^{87}$ What happened in the immediate aftermath of this interrogation is not clear, for an entire leaf is missing from the manuscript. When the text resumes, we find Yùsuf announcing that these foreign clergymen were to be burned alive like the other Christians of Najrān. ${ }^{88}$ At this point there follows another large lacuna in the text, and it is not until the beginning of the following chapter that the text can be reconstructed, though by then the narrative has moved on to the unrelated issue of a woman martyr named Trwyb' (=Zarwība?). Textual lacunae aside, it is likely that Yōnan was martyred together with his fellow clergymen. Whether other Aksumites resided in Najrān at this time, as they appear to have during the mid-3rd century, ${ }^{89}$ is not clear from what survives of the Book of the Himyarites.

That the Aksumites maintained ties with Soqoțā during the 6th century is evident from the account of Cosmas Indicopleustes, a merchant who, during his visit to Ethiopia ca. 518 met Greek-speaking merchants from Soqoțrā. ${ }^{90}$

85 According to the Periplus of the Erythraean Sea (Casson, Periplus, §16.6.8-13), the merchants of Mouza, the name by which the anonymous author designates al-Mukhā', conducted commerce with the port of Rhapta, located somewhere on the coast of what is now Tanzania.

86 Moberg, Book of the Himyarites, p. 14b (Syriac text).

87 Moberg, Book of the Himyarites, ibid.

88 Moberg, Book of the Himyarites, p. 15 a.

89 See §3.3.1.

90 Cosmas Indicopleustes, Topographie chrétienne, ed. and trans. Wolska-Conus, §3.65.12-13. 
That Aksumites, in turn, traveled to Soqoțrā is evident from three Ge'ez graffiti from the grotto at Hōq, which, according to Robin, are probably of Christian origin and of 6th-century date. ${ }^{91}$ The first of these (2:25) reads șh $[f] B d^{\prime}$ "He has written: Blessed!", 92 the second (2:27) $B d[$ [ ] $]$ ș[f] "Blessed!' he has written", ${ }^{93}$ the third (2:34) șhf Bṣ "He has written: Blessed!". ${ }^{94}$ Robin draws attention to parallel phrases in Ge'ez literature in hagiographies of the Aksumite-period saint Lībānōs, according to which the saint had written the Beatitudes in the country of Degsā (hallawa șahîfō Badūūān haba madra Dagsāa). ${ }^{95}$ As with the Ge'ez graffiti from earlier periods that have become known at Hōq, ${ }^{96}$ however, these three graffiti constitute a rather dubious foundation on which to base the hypothesis of a permanent Aksumite colony on Soqoțrā. While Christianity is known to have established a presence on the island by the 6th century, ${ }^{97}$ the fact that Soqoțī Christians adhered to the Nestorian Church, as opposed to the Miaphysite Church to which the Aksumites belonged, ${ }^{98}$ suggests that the Aksumites had little influence on the island. Indeed, it is not even clear whether, following the invasions of Ḥimyar in 518 and 525 , the Aksumite sphere of influence even encompassed Soqoțrā.

91 Robin, "Sudarabiques et Aksūmite", p. 440.

92 Robin in Strauch, "Catalogue", pp. 54-55.

93 Robin in Strauch, "Catalogue", p. 57.

94 Robin in Strauch, "Catalogue", p. 64.

95 Robin in Strauch, "Catalogue", p. 55.

$96 \quad$ See $\$ 3 \cdot 3 \cdot 2$.

97 In his description of Soqoțrā, Cosmas Indicopleustes, Topographie chrétienne, ed. and trans. Wolska-Conus, $\S 3 \cdot 65.6-13$, alludes to the presence on the island of clerics ordained in Persia, i.e. the Sāsānid Empire, and a multitude of Christians. Such a community can only have formed over a period of several decades, if not generations, in which case the origins of Soqoțī Christianity would date back to at least the $5^{\text {th }}$ century.

98 On the history of Soqoțī Christianity, see Beckingham, "Some Notes", passim; Biedermann, Soqotra, pp. 39-63. Although the chronicler João de Barros (d. 1570) claims that the Christians of Soqoțrā belonged to the same sect of Christianity as the Ethiopians, i.e. Miaphysite Christianity (Beckingham, "Some Notes", p. 174), this idea is likely to have arisen from a lack of awareness on the part of his informants of the doctrinal nuances of eastern Christianity. Of de Barros' statement that Soqoțrī Christians chanted in "Chaldaean" (caldeu), Beckingham (ibid., p. 180 [n. 5]) states that "[t]his would normally mean Syriac, but the word is sometimes used by the Portuguese for Ge'ez". Since, however, the Ethiopian Church is not known to have exerted its influence on Soqoțrā during any period, it is highly unlikely that the indigenous Christians of the island knew Ge'ez. The "Chaldaean" in which they chanted is therefore likely to have been either Syriac-regardless of whether or not the locals still understood it — or even, perhaps, the Soqoțī language, which the Portuguese categorized as "Chaldaean" for the sake of convenience. That a significant language barrier separated the Portuguese from the indigenous Soqoțīs should not be forgotten. 


\subsection{The Ethiopian Community under 'Abrahä}

With the reign of 'Abrəhā (ca. 531/5-560) we come to the final period of the history of the Aksumite diaspora in South Arabia. Where this period differs from those that preceded it is that now the Aksumites residing in South Arabia were the subjects of a regime that had effectively cast off the yoke of Aksumite rule. In fact, it is by no means clear to what extent—if at all-the members of this diaspora continued to self-identify as Aksumite once 'Abrəhā had achieved independence from Aksum. For this period, we are primarily dependent on Sabaic inscriptions dating from his reign as well as early medieval Arabic sources, together with a brief summary of his reign supplied by the Roman historian Procopius (d. 554). That Arabic sources show particular interest in 'Abrəhā is due primarily to the Islamic tradition of his having led an ill-fated campaign to destroy Mecca's Ka'ba shrine. ${ }^{99}$ Our concern here, however, shall be with the way in which the documentation for 'Abrəhā's reign presents the Ethiopian community in South Arabia at the time.

\subsubsection{Sabaic References: CIH 541}

Only once, in his famous inscription from the dam at Mārib, CIH 541, does Sabaic documentation from 'Abrəhā's reign allude to Aksum, and then only indirectly, in connection with the reception of a diplomatic delegation from the $n a g \bar{a} s \bar{l}$, i.e. the Aksumite king $\left(m h s^{2} k t n g s^{2} y^{n}\right) \cdot{ }^{100}$ When the Ethiopian followers of 'Abrəhā are mentioned elsewhere in the same inscription, they are referred to as "Ethiopians" $\left(H b s^{2} t\right.$ or ' $\left.h b s^{2 n}\right)$ rather than as "Aksumites" $\left({ }^{\prime} k s^{1} m^{n}\right)$. Thus in one passage, 'Abrəhā's armed forces are said to have been comprised of both "Ethiopians and Himyarites by the thousands" $\left(\mathrm{Hbs}^{2} \mathrm{t}[\mathrm{w}\right.$ - $] \mathrm{Hmyr}^{\mathrm{m}}$ $b$ - $^{\prime \prime}\left(f^{m}\right) \cdot{ }^{101}$ Ethiopians and Himyarites are paired in another passage recording their participation in repair work at the Mārib dam. The passage in question states that, when a plague $(d l l)$ struck the region and caused deaths among the tribes, 'Abrəhā "dismissed them, his Ethiopians and his Himyarites" ('dnw l$h m w$ l-'hbs ${ }^{2}-h m w w$-'hmr-hmw), until the plague subsided. ${ }^{102}$ Apart from 'Abrəhā himself, the dam inscription also refers to four other Ethiopians by name. The first was one Gerā Dhū-Zabānir (Grh D-Zbnr), ${ }^{103}$ whose name

al-Ṭabarī, Annales, ed. de Goeje, vol. 2, pp. 936-945. Traditions about 'Abrəhā's campaign against Mecca are based on Sürat al-Fül "The Chapter of the Elephant", the 105th chapter of the Qurān, though that text, which consists of only five verses, contains no mention of 'Abrəhā, the Ka'ba, or Mecca.

$100 \mathrm{CIH}$ 541/88 (Müller, Sabäische Inschriften, p. 115).

101 CIH 541/25-6 (Müller, Sabäische Inschriften, p. 112).

102 CIH 541/74-5 (Müller, Sabäische Inschriften, p. 114).

103 CIH 541/19 (Müller, Sabäische Inschriften, p. 111). 
Müller associates with the masculine personal and tribal name of Gerā, attested in Tigre. ${ }^{104}$ This Gerā, so CıH 541 informs us, had been sent by 'Abrəhā to suppress a rebellion in the region of Mashriq a ${ }^{\text {an }}$, located in southern Yemen between the Yemeni highlands and the Hadramawt, only to be killed himself by the rebels. ${ }^{105}$ Two other Ethiopians are reported to have served as governors (hlyf) during 'Abrəhā's reign, one named Watțā $(W t h)$ and the other 'Awīdā ('wdh). ${ }^{106}$ Although Müller identifies both as Ethiopian by origin, the inscription states that they were affiliated with Gadan ${ }^{\mathrm{um}, 107}$ a Sabaean tribe which probably had its homeland in the area around Mārib but also had members at Șan ‘̄à', Jiḥāna, and Najrān, as well as in Wādī al-Jawf. ${ }^{108}$ It is possible that Waț̣ā and 'Awīdā were associated with Gadan'um because they exercised some form of political authority over this tribe or, alternatively, because they had been clients of the tribe-in the same way, perhaps, that non-Arab converts to Islam became clients (mawāl $\bar{\imath})$ of Arab tribes during the early Islamic period. ${ }^{109}$ Another Ethiopian affiliated with a South Arabian tribe-and the fourth Ethiopian besides 'Abrəhā to be mentioned by name in CiH 541-was one of 'Abrəhā's own sons, referred to in the inscription as 'Aksūm Dhū-Ma'āhir ('brh $D-M c h r)$, who headed some sort of entourage (' $\left.l m t^{m}\right)$ that accompanied 'Abrəhā to Mārib. ${ }^{110}$ This individual is undoubtedly the Yaksūm identified in Arabic sources as a son and successor of 'Abrəhā, the Arabic form of his name perhaps deriving from Amharic *Ya-Aksūm "He of Aksum".111 Ma'āhir, with which he was affiliated, was a Himyarite princely lineage based $150-200 \mathrm{~km}$ southeast of Șanā’a Once again, the nature of this affiliation is not entirely clear.

Among the Ethiopians mentioned in $\mathrm{CIH} 541$ there would no doubt have been those who, like 'Abrəhā, had arrived in Himyar with the Aksumite invasion of 525, if not before. Others might have been among the two armed forces which, according to Procopius, ${ }^{112}$ Kālēb had sent to Ḥimyar in a vain effort to remove 'Abrəhā from power. Unfortunately, neither the extant Sabaic sources nor Procopius give us any sense of the size of the Ethiopian community in

\footnotetext{
104 Müller, "Abessinier", p. 167.

105 CІн 541/19-20 (Müller, Sabäische Inschriften, p. 111).

106 CIH 541/36-7 (Müller, Sabäische Inschriften, p. 112).

107 Müller, "Abessinier", p. 167.

108 Robin, "Matériaux", p. 160.

109 Crone, Slaves on Horses, pp. 49-57 and passim.

110 CIH 541/82-83 (Müller, Sabäische Inschriften, p. 115).

111 Cf. Amharic Yāmlāk (< * $y a+A m l a ̄ k)$, "he of God", and Yāmrōt (< *ya + amrōt) "he of love/ pleasure". Worthy of note in this regard is a 1oth-century Coptic text in which the Queen of Sheba is called Iesaba, a name which Vycichl ("Amharisme") derives from the Amharic * $y a-S a b \bar{a}$ "she of Sheba".

112 Procopius, History of the Wars, trans. Dewing, §1.20.2.
} 
South Arabia during 'Abrəhä's time. As we have seen, there were some 300 Aksumites who had settled at Zafär alone in the aftermath of the invasion of 518 . Although most of these are likely to have been killed by the forces of Yüsuf 'As'ar Yath'ar, the number of Aksumites residing in South Arabia would undoubtedly have been replenished because of the invasion led by Kālēb in 525 . When one considers as well the deserters from the two subsequent invasions sent by Kālēb, it is likely that several thousand Ethiopians resided in South Arabia in 'Abrəhā's day.

\subsubsection{Arabic References: al-Ṭabarī}

Turning to the Arabic sources, the most detailed-if perhaps apocryphalaccount of 'Abrəhā's coming to power is preserved by Muhammad bin Jarīr alṬabarī (d. 923) and is based on a tradition related by Muhammad ibn Isḥāq (d. 767?). According to this account, 'Abrəhā seized power as a result of a singlecombat encounter with one Aryāt, a general in the Aksumite army who remained in authority in South Arabia for several years after what was apparently the invasion of 525 . Aryāt was rather treacherously put to death by a slave of 'Abrəhā's named 'Atwada, after which "the army of Aryāt flocked to 'Abrəhā and all of the Ethiopians in Yemen gathered together (around him)" (inșarafa jund Aryāt ilā Abraha fa-jtama'at il-Habasha bil-Yaman). ${ }^{113}$ Aryāț, it should be noted in passing, is known solely from Arabic sources. ${ }^{114}$ It is possible that the story of his demise preserves some vague memory of 'Abrəhā's overthrow of Sumūyafa' 'Ashwa', an individual who is otherwise unknown to Arabic tradition. Alternatively, it is possible that Aryāt was the leader of one of the two punitive campaigns, which Kālēb had sent against 'Abrəhā, according to Procopius, but that, with the passage of time, he came to be associated in Arabic tradition with the invasion of 525. The account of Hishām bin Muhammad alKalbī (d. 819), also preserved by al-Ṭabarī, follows more or less the same narrative, but gives a different name to 'Abrəhā's slave, which in the extant manuscripts of al-Ṭabarī appears in the form 'rnjdh or 'rbjdh, the vocalization of which is uncertain. ${ }^{115}$

\footnotetext{
113 al-Ṭabarī, Annales, ed. de Goeje, vol. 2, p. 932.

114 'Alī bin al-Ḥusayn al-Mas'ūdī (d. 956) gives the full name of Aryāṭ as Aryāṭ bin Aṣhama (al-Mas'ūdī, Murūj, ed. Dāghir, vol. 2, p. 52). It is possible, though, that the Așhama element was borrowed from Arabic traditions about the 7th-century Ethiopian king alAșhama, who supposedly granted asylum to the Muslims when the latter were faced with persecution by the pagan Quraysh. Accounts of al-Așhama may preserved memory of the seventh-century Aksumite king 'glla-Ṣaḥām (Fiaccadori, “Gllä Șäḥam”).

115 al-Ṭabarī, Annales, ed. de Goeje, vol. 2, p. 931.
} 
Whatever the origins or historicity of the story of the clash between 'Abrəhā and Aryāt, the regime which 'Abrəhā established in South Arabia was not to last for long. According to Arabic sources, it was brought to an end through the combined efforts of disenfranchised Ḥimyarites and their Sāsānid allies ca. 570. Once again, al-Tabarī, drawing on earlier sources, preserves the most detailed account. Citing Ibn Isḥāq and Hishām bin Muhammad, al-Ṭabarī states that a Himyarite nobleman named Sayf bin Dhī Yazan appealed to Kisrā, i.e. the Sāsānid emperor Khusraw Anushiruvān (r. 531-579), for aid in expelling the Ethiopians from his country. Eventually, the emperor sent an invasion force to South Arabia under the command of one Wahriz, ${ }^{116}$ which succeeded in killing Masrūq and bringing Sayf to power. ${ }^{117}$ Once in power, Sayf launched what amounted to an all-out slaughter of South Arabia's Ethiopian population.

'Adā 'alā l-Ḥabasha fa-ja'ala yaqtuluhā wa-yabquru l-nisāahā 'ammā fì buṭunihā idhā afnāhā illā baqāyā dhalīla qalīla fa-ttakhadhahum khawalan.118

He attacked the Ethiopians and began to kill them and ripped out (the fetuses) which their women had in their bellies, until he had annihilated all but a few wretched remnants of them, whom he seized as slaves.

It was not long, however, before a few of these slaves rose up and killed Sayf. Angered by the assassination of his client, Kisrā dispatched Wahriz once more to South Arabia. This time, the punishment meted out to what remained of the Ethiopian community was harsher still.

Ammarahu an lā yatruk bil-Yaman aswad'a wa-lā walad 'Arabiyyat ${ }^{\text {in }}$ min aswad illā qatalahu șaghīiran aw kabīiran wa-lā yadac rajulan ja' dan qațațan qad sharika fîhi l-Sūdān. ${ }^{119}$

He (i.e. Kisrā) commanded him not to leave in Yemen a black or the child of an Arab woman by a black without killing him, young or old; nor to let live a single curly- or crispy-haired man with whom the blacks had been involved.

116 Wahriz is in fact a title rather than a personal name (Potts, "Sasanian Relationship", p. 207).

117 al-Ṭabarī, Annales, ed. de Goeje, vol. 2, pp. 945-957.

118 al-Ṭabarī, Annales, ed. de Goeje, vol. 2, p. 957.

119 Ibid. 
It would appear from this passage that there was a certain degree of intermarriage between Ethiopians and local South Arabian women during the 6th century. Whether the women alluded to in connection with the slaughter unleashed by Sayf were also the South Arabian spouses (or concubines) of resident Ethiopians or were themselves of Ethiopian extraction is not clear.

As a caveat, it must be stressed that the Arabic accounts of the fall of the Ethiopian regime in Himyar undoubtedly contain a large amount of spurious material, as a result of the passage of time between the events they describe and the time when they were written down, coupled with the introduction of hyperbolic and legendary elements. Nevertheless, the Sāsānid invasion-and eventual conquest - of Himyar was an event known to late 6th-century Roman historians. This development is treated, if only briefly, by the late 6thcentury historians John of Epiphania ${ }^{120}$ and Theophanes of Byzantium. ${ }^{121} \mathrm{Al}-$ though neither author has anything to say about the fate of South Arabia's Ethiopian community in the aftermath of the Sāsānid takeover, it is striking that the Arabic accounts of the Muslim wars of conquest in the 7 th and early 8th centuries say nothing about the participation of South Arabia-based Ethiopian troops. This is despite the well-documented participation of indigenous South Arabian tribes in these wars, ${ }^{122}$ including groups like Mahra, ${ }^{123}$ which had been relatively unimportant in the context of late pre-Islamic history. Although it is not impossible that some Ethiopians were subsumed anonymously within the ranks of South Arabian tribes, one would not expect such a scenario had they constituted a large community which cohered as a self-contained block, as the Ethiopians had in South Arabia during the 3 rd and 6th centuries. Likewise, while the Meccan tribe of Quraysh is known to have traded with South Arabia, ${ }^{124}$ contact with the Ethiopians does not seem to have taken place in the context of trade with South Arabia. ${ }^{125}$ More likely, Qurashī merchants encountered Ethiopians either in the course of visits to Ethiopia itself, ${ }^{126}$ or through transactions with Ethiopians who had traveled to Mecca. ${ }^{127}$

\footnotetext{
120 Theophylact Simocatta, History, trans. Whitby/Whitby, p. 85 (iii.9.3-6).

121 Photius, Bibliothèque, ed. and trans. Henry, vol. 1, p. 78 (64.15-17).

122 Al-Medej, Yemeni Relations, pp. 110-139; Smith, "Yemenite History".

123 Hence the settlement of Mahra tribes in the conquered provinces following the Muslim invasions (al-Medej, Yemeni Relations, pp. 162; 165; 166).

124 Crone, Meccan Trade, pp. 120-124; 141-144; 149; 150; 152; 163.

125 Crone, Meccan Trade, pp. 126-128.

126 Crone, Meccan Trade, pp. 124-129. The nature of Meccan trade with Ethiopia is unclear, not least because, in contrast to other regions with which Mecca traded in late pre-Islamic times, Arabic sources fail to mention any place-names within Ethiopia (ibid., p. 125).

127 Crone, Meccan Trade, pp. 125-126.
} 
The most plausible conclusion, then, is that South Arabia's Ethiopian population was indeed drastically reduced in number following the overthrow of the regime established by 'Abrəhā in the 570s, whether through slaughter of the sort described in Arabic sources, by a mass exodus of Ethiopians from the region, or, most probably, by a combination of both factors.

\section{$7 \quad$ Conclusion}

Sabaic inscriptions, supplemented by Syriac, Greek, and Arabic texts, provide a record of Aksumite Ethiopian contact with, and settlement in, South Arabia from the late 2nd century down to the mid-sixth. To be sure, there are some noteworthy gaps in this textual record. Thus, only one relevant text, the Sabaic inscription Ir 28, dates from the 4th century, and even this inscription documents diplomatic relations between Aksum and Himyar rather than Aksumite settlement in Himyar. As for the textual record for the $5^{\text {th }}$ century, this remains completely silent on the issue of either a possible Aksumite presence in South Arabia or Himyarite relations with Aksum at that time. The most abundant and detailed documentation of the Aksumite community in South Arabia dates from the 6th century.

It must be stressed that the textual data on which this study is largely based represents what must have been only a portion of the Aksumite expatriate community in South Arabia during late pre-Islamic times. Not surprisingly, those Aksumites who warranted mention by name in the textual sources were almost entirely of elite status, including such individuals as community or religious leaders, governors, ambassadors, and kings. Ceramics from Qāni' supplement this record by providing evidence of the (at least seasonal) presence of Aksumite merchants in South Arabia, a group not represented in textual sources. As in medieval and modern Yemen, there would undoubtedly have been Ethiopian slaves and laborers in late pre-Islamic South Arabia though, for obvious reasons, such low-status individuals are absent from both the textual and, so far as we can tell, the archaeological record-barring the case of 'Abrəhā's slave 'Atwada, who might never have existed.

Despite the incompleteness of the extant data, it can be confidently stated that no country is known to have maintained relations with South Arabia over as long a stretch of time as Ethiopia. This is hardly surprising, given the close geographical proximity of Ethiopia and South Arabia. As observed at the beginning of this study, Aksum was the only sub-Saharan state known to have expanded outside Africa at any point in history. The record of its activities in South Arabia are equally unique in that they provide the only extensive corpus 
of written material documenting the presence of sub-Saharan Africans in the pre-Islamic Near East. ${ }^{128}$

\section{Bibliography}

\section{Primary Sources}

'Arabfaqīh, Shihāb al-Dīn, Tuhfat al-zamān aw futūh al-habashha. Al-șirā' al-șümālī al-ḩabashī fì l-qarn al-sādis 'ashar al-mülādī, ed. F.M. Shaltūt, Cairo 1971.

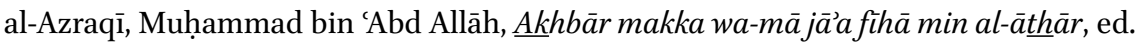
R. al-Ṣăliḥ Malhas, 2 vols., Mecca 1965.

Casson, L., The Periplus maris Erythraei: Text with Introduction, Translation, and Commentary, Princeton 1989.

Cosmas Indicopleustes, Topographie chrétienne, ed. and trans. W. Wolska-Conus, 3 vols., Paris 1968-73.

al-Hamdānī, al-Ḥasan bin Ạ̣mad, Sịfat jazīrat al-'arab, ed. M. al-Ḥawālī, al-Riyāḍ 1974. al-Mas'ūdī, 'Alī bin al-Ḥusayn, Murūj al-dhahab wa-ma'ādin al-jawāhir, ed. Y.A. Dāghir, 4 vols., Beirut 1965 .

Moberg, A. (ed. and trans.), The Book of the Himyarites. Fragments of a Hitherto Unknown Syriac Work, Lund 1924.

Photius, Bibliothèque, ed. and trans. R. Henry, 9 vols., Paris 1959.

Procopius, History of the Wars, trans. H.B. Dewing, Cambridge, Massachusetts 2006.

Rufinus, The Church History of Rufinus of Aquileia, Books 10 and 11 , trans. P.R. Amidon, New York 1997.

Simeon of Bēth Arsham, La lettera di Simeone vescovo di Bêt Arsâm sopra i martiri omer$i t i$, ed. and trans. I. Guidi, Rome 1881.

128 One could add, of course, the references to Africans, specifically Ethiopians, in preIslamic Arabic poetry, though such references tend on the whole to be made only in passing, and there is at times some doubt as to how authentically pre-Islamic this corpus is. Similarly, although early Islamic sources in Arabic allude to the Ethiopian presence in the Hijāz in pre-Islamic times, such sources post-date the events they describe by several centuries, in contrast to the Sabaic, Greek, and Syriac sources treated in this study, which are either contemporary with the events they describe or post-date such events by at most a few decades. It should also be noted that, although the Aksumite community of South Arabia is the only African diaspora community in the ancient Near East of which we can meaningfully speak, Graeco-Roman texts and art have left a fairly substantial documentation of a sub-Saharan African presence in the Mediterranean world in Classical Antiquity (Snowden, Blacks in Antiquity). The main difference there, however, is that sub-Saharan Africans were never in a position of political power in the Mediterranean, as the Aksumites were in South Arabia. 
al-Ṭabarī, Muḥammad bin Jarīr, Annales quos scripsit Abu Djafar Mohammed ibn Djarir at-Tabari = Ta'rīkh al-rusul wal-mulūk, ed. M.J. de Goeje, 15 vols., Beirut 1965.

Theophylact Simocatta, The History of Theophylact Simocatta. An English Translation with Introduction and Notes, trans. M. Whitby/M. Whitby, Oxford and New York 1986.

\section{Secondary Literature}

Arzhanov, Y., "Zeugnisse über Kontakte zwischen Juden und Christen im vorislamischen Arabien", Oriens Christianus 92 (2008), 79-93.

Beckingham, C.F., "Some Notes on the History of Socotra", in R.L. Bidwell/G.R. Smith (eds.), Arabian and Islamic Studies. Articles Presented to R.B. Serjeant on the Occasion of his Retirement from the Sir Thomas Adam's Chair of Arabic at the University of Cambridge, London and New York 1983, pp. 172-181.

Biedermann, Z., Soqotra: Geschichte einer christlichen Insel im Indischen Ozean vom Altertum bis zur frühen Neuzeit, Wiesbaden 2006.

Bron, F., "Sur une nouvelle inscription historique sabéenne", Studi Epigrafici e Linguistici 10 (1993), 79-83.

Crone, P., Slaves on Horses. The Evolution of the Islamic Polity, Cambridge 1980.

Crone, P., Meccan Trade and the Rise of Islam, Princeton 1987.

Drewes, A.J./Schneider, R., "Les inscriptions de la période pré-axoumite", in E. Bernand/A.J. Drewes/R. Schneider (eds.), Recueil des inscriptions de l'Éthiopie des périodes pré-axoumite et axoumite. Tome I: Les documents, Paris 1991, pp. 65-213.

Drewes/R. Schneider, "Les inscriptions de la période axoumite. A. Les inscriptions guèzes", in E. Bernand/A.J. Drewes/R. Schneider (eds.), Recueil des inscriptions de l'Éthiopie des périodes pré-axoumite et axoumite. Tome I: Les documents, Paris 1991, pp. $215^{-358 .}$

Fiaccadori, G., “ヨllä Șäḥam”, in S. Uhlig (ed.), Encyclopaedia Aethiopica, vol. 2: D-Ha, Wiesbaden 2005, pp. 262-263.

Gajda, I., Le royaume de Himyar à l'époque monothéiste. L'histoire de l'Arabie du sud ancienne de la fin du IV siècle de l'ère chrétienne jusqu'à l'avènement de l'Islam, Paris 2009 .

Hatke, G., Africans in Arabia Felix. Aksumite Relations with Himyar in the Sixth Century CE., unpubl. PhD diss., Princeton University, Princeton 2011.

Hatke, G., Aksum and Nubia. Warfare, Commerce, and Political Fictions in Ancient Northeast Africa, New York 2013.

Hayajneh, H., "Abessinisches aus den arabischen Überlieferungen. Randbemerkungen", in H. Elliesie (ed.), Multidisciplinary Views on the Horn of Africa (Studien zum Horn von Afrika 1), Cologne 2014, pp. 497-510.

al-Iryānī, M.'A., F̄̄ Tảrīkh al-Yaman: Sharh wa-ta'līq 'alā nuqūsh lam tunshar. 34 naqs $\underline{s}^{\text {an }}$ min majmū'at 'Alī 'Abd Allāh al-Kahālì, Șan'ā' 1973. 
Jamme, A., Sabaean Inscriptions from Maḥram Bilqîs (Mârib), Baltimore 1962.

Jamme, A.. The al-Uqlah Texts (Documentation sud-arabe 3), Washington 1963.

Kropp, M.S., "Schriften und Sprachen im Kontakt. Sabäisch in Äthiopien und die ersten

Zeugnisse der äthiopischen Sprache und Schrift", in S. Wenig (ed.), In Kaiserlichem Auftrag: Die Deutsche Aksum-Expedition 1906 unter Enno Littmann, vol. 2: Altertumskundliche Untersuchungen der DAE in Tigray/Äthiopien, Wiesbaden 2011, pp. 323-337.

Maraqten, M., "Eine neuentdeckte altsabäische Inschrift aus Mārib", in W. Arnold/ M. Jursa/W.W. Müller/S. Procházka (eds.), Philologisches und Historisches zwischen Anatolien und Sokotra. Analecta Semitica In memoriam Alexander Sima, Wiesbaden 2009, pp. 241-246.

Marrassini, P., "The Semites in Abyssinia. Onomastic and Lexicographical Notes", in L. Kogan (ed.), Studia Semitica, Moscow 2003, pp. 141-151.

al-Medej, A.M., Yemeni Relations with the Central Islamic Authorities (9-233/630-847). A Political History, unpubl. PhD diss., Durham University, http://etheses.dur.ac .uk/952/, Durham 1983.

Müller, W.W., "Abessinier und ihre Namen und Titel in vorislamischen südarabischen Texten", Neue Ephemeris für semitische Epigraphik 3 (1978), 159-168.

Müller, W.W., "Südarabisches zum Namen Aksum”, Aethiopica 1 (1998), 217-220.

Müller, W.W., Sabäische Inschriften nach Ären datiert. Bibliographie, Texte und Glossar, Wiesbaden 2010.

Müller, W.W., "Äthiopische Inschriftenfragmente aus der himjarischen Haupstadt Zafār", Aethiopica 15 (2013), 7-21.

Murray, O., "Review: East of Suez", The Classical Review (New Series) 17/1 (1967), 79-81.

Phillipson, D.W., Foundations of an African Civilization. Aksum \& the Northern Horn, $1000 B C-A D$ 1300, Woodbridge 2012.

Potts, D.T., "The Sasanian Relationship with South Arabia. Literary, Epigraphic and Oral Historical Perspectives", Studia Iranica 37 (2008), 197-213.

Robin, C.J., "La première intervention abyssine en Arabie méridionale (de 200 à 270 de l'ère chrétienne environ)", in T. Beyene (ed.), Proceedings of the Eighth International Conference of Ethiopian Studies, vol. 2., Addis Ababa 1989, pp. 147-162.

Robin, C.J., "Le royaume hujride, dit « royaume de Kinda », entre Himyar et Byzance", Comptes rendus des séances de l'Académie des Inscriptions et Belles-Lettres 140/2 (1996), 665-714.

Robin, C.J., "La fin du Royaume de Ma'īn”, in R. Gyselen (ed.), Parfums d'Orient (Res Orientales 11), Bures-sur-Yvette 1998, pp. 177-188.

Robin, C.J., "Himyar et Israël", Comptes Rendus de l'Académie des Inscriptions et Belles Lettres 148/2 (2004), 831-908.

Robin, C.J., "Himyar au ive siècle de l'ère chrétienne. Analyse des données chronologiques et essai de mise en ordre", Archäologische Berichte aus dem Yemen 10 (2005), 133-151. 
Robin, C.J., "Sudarabiques et Aksūmite à Suquțra d'après les inscriptions de la grotte de Hōq", in I. Strauch (ed.), Foreign Sailors on Socotra. The Inscriptions and Drawings from the Cave Hoq, Bremen 2012, pp. 438-442.

Robin, C.J., "Matériaux pour une prosopographie de l'Arabie antique. Les noblesses sabéenne et himyarite avant et après l'Islam", in C.J. Robin/J. Schiettecatte (eds.), Les préludes de l'Islam. Ruptures et continuités des civilisations du ProcheOrient, de l'Afrique orientale, de l'Arabie et de l'Inde à la veille de l'Islam, Paris 2013, pp. 129-271.

Robin, C.J., "Saba' et la Khawlān du nord (Khawlān Gudādān). L'organisation et la gestion des conquêtes par les royaumes d'Arabie méridionale", in A.V. Sedov (ed.), Arabian and Islamic Studies. A Collection of Papers in Honour of Mikhail Borishovich Piotrovskij on the Occasion of His 7oth Birthday, Moscow 2014, pp. 156-203.

Robin, C.J./Maigret, A. de, "Le Grand Temple de Yéha (Tigray, Éthiopie), après la première campagne de fouilles de la Mission française (1998)", Comptes Rendus de l'Académie des Inscriptions et Belles Lettres 142 (1998), 737-798.

Robin, C.J./Ṭayrān, S., "Soixante-dix ans avant l'Islam. L'Arabie toute entière dominée par un roi chrétien", Comptes Rendus de l'Académie des Inscriptions et Belles Lettres 1 (2012), 525-553.

Schiettecatte, J., "L'antique Najrān. Confrontations des données archéologiques et des sources écrites", in J. Beaucamp/F. Briquel-Chatonnet/C.J. Robin (eds.), Juifs et chrétiens en Arabie aux $v^{e}$ et vi ${ }^{e}$ siècles: Regards croisés sur les sources. Actes du colloque de novembre 2008, Paris 2010, pp. 11-37.

Sedov, A.V., "Les fouilles de secteur 3. La synagogue", in J.-F. Salles/A.V. Sedov (eds.), Qāni': Le port antique du Hadramawt entre la Méditerranée, l'Afrique et l'Inde. Fouilles russes 1972, 1985-89, 1991, 1993-94, Turnhout 2010a, pp. 87-122.

Sedov, A.V., "Stratigraphy and Development of the Site. Preliminary Remarks", in J.-F. Salles/A.V. Sedov, Qāni’: Le port antique du Hadramawt entre la Méditerranée, l'Afrique et l'Inde. Fouilles russes 1972, 1985-89, 1991, 1993-94, Tournhout 2010b, pp. 371-380.

Shahid, I., The Martyrs of Najrân. New Documents, Brussels 1971.

Shitomi, Y., "Une note sur 'ṣd", Raydān 4 (1981), 127-129.

Smith, G.R., "Yemenite History-Problems and Misconceptions", Proceedings of the Seminar for Arabian Studies 20 (1990), 131-139.

Snowden, F.M., Blacks in Antiquity, Ethiopians in the Greco-Roman Experience, Cambridge, Massachusetts 1970.

Speidel, M.A., "Außerhalb des Reiches? Zu neuen lateinischen Inschriften aus SaudiArabien und zur Ausdehnung der römischen Herrschaft am Roten Meer", Zeitschrift für Papyrologie und Epigraphik 163 (2007), 296-306.

Speidel, M.A., "Almaqah in Rom? Zu den Beziehungen zwischen dem kaiserzeitlichen Imperium Romanum und Südarabien im Spiegel der Dokumentarischen Überlieferung", Zeitschrift für Papyrologie und Epigraphik 194 (2015), 241-258. 
Strauch, I., "Catalogue of inscriptions and drawings in the cave Hoq", in I. Strauch (ed.), Foreign Sailors on Socotra. The Inscriptions and Drawings from the Cave Hoq, Bremen 2012, pp. 25-218.

Vycichl, W., "Un amharisme dans un texte copte", Annales d'Éthiopie 2/2 (1957), 247-248.

Yule, P., Late Antique Arabia. Zafār, Capital of Himyar, Wiesbaden 2013. 